\title{
Nanodarts, nanoblades, and nanospikes:
}

\section{Mechano-bactericidal nanostructures and where to find them}

Nicholas Lin ${ }^{\mathrm{a}, \mathrm{b}}$, Paula Berton ${ }^{\mathrm{b}}$, Christopher Moraes ${ }^{\mathrm{a}}$, Robin D. Rogers ${ }^{\mathrm{b}}$, Nathalie Tufenkji ${ }^{a^{*}}$

${ }^{a}$ Department of Chemical Engineering, McGill University, 3610 University St., Montreal, QC H3A OC5, Canada.

${ }^{b}$ Department of Chemistry, McGill University, 801 Sherbrooke St. West, Montreal, QC H3A OB8, Canada.

*Corresponding author, E-mail: nathalie.tufenkji@mcgill.ca; 514.398 .2999 (phone); $514.398 .6678(f a x)$ 


\section{Abstract}

Over the past ten years, a next-generation approach to combat bacterial contamination has emerged: one which employs nanostructure geometry to deliver lethal mechanical forces causing bacterial cell death. In this review, we first discuss advances in both colloidal and topographical nanostructures shown to exhibit such "mechano-bactericidal" mechanisms of action. Next, we highlight work from pioneering research groups in this area of antibacterials. Finally, we provide suggestions for unexplored research topics that would benefit the field of mechano-bactericidal nanostructures. Traditionally, antibacterial materials are loaded with antibacterial agents with the expectation that these agents will be released in a timely fashion to reach their intended bacterial metabolic target at a sufficient concentration. Such antibacterial approaches, generally categorized as chemical-based, face design drawbacks as compounds diffuse in all directions, leach into the environment, and require replenishing. In contrast, due to their mechanisms of action, mechano-bactericidal nanostructures can benefit from sustainable opportunities. Namely, mechano-bactericidal efficacy needs not replenishing since they are not consumed metabolically, nor are they designed to release or leach compounds. For this same reason, however, their action is limited to the bacterial cells that have made direct contact with mechano-bactericidal nanostructures. As suspended colloids, mechano-bactericidal nanostructures such as carbon nanotubes and graphene nanosheets can pierce or slice bacterial membranes. Alternatively, surface topography such as mechano-bactericidal nanopillars and nanospikes can inflict critical membrane damage to microorganisms perched upon them, leading to subsequent cell lysis and death. Despite the infancy of this area of research, materials constructed from these nanostructures show remarkable antibacterial potential worthy of further investigation.

Keywords: mechano-bactericidal; antibacterial; topography; carbon nanotube; graphene; cicada wing 


\section{Introduction}

Bacterial contamination is detrimental to industrial processes and hazardous to human health. The undesirable presence of bacteria is traditionally eliminated by chemical-based approaches relying on the diffusive release of antibacterial agents [1]. Today, these agents are loaded, coated, or impregnated into a myriad of materials for industrial applications and consumer products alike. However, systems designed to release antibacterial agents result in the leaching of said agents into the environment. In addition to unintended toxicity jeopardizing indigenous organisms, leached compounds produce a sublethal background dose that can foster the development of resistance mechanisms $[2,3]$. Even if these environmental and health aspects are overlooked, from a product design perspective, release-based antibacterial materials in practice are often ineffective. Their burstrelease kinetics are initially highly toxic but concentration decreases rapidly, thus requiring replenishment or replacement, and released compounds ultimately do not reach the intended targets at a sufficient concentration since diffusion is uncontrolled and directionless $[4,5]$.

Novel, non-diffusive strategies to prevent bacterial proliferation are therefore highly sought after and are a focal point in current antibacterial research $[1,2,6,7]$. For example, covalently functionalized, non-leaching antibacterial coatings have been designed to mitigate the excessive release of compounds into the environment $[2,8]$. However, even when a surface is chemically unfavorable, ions and macromolecules such as proteins and polysaccharides secreted by bacteria or from the local environment can form a "conditioning film" on the surface. This acts to mask antibacterial functional groups so that adhesion and bacterial proliferation can proceed, rendering the covalently functionalized material inefficient $[9,10]$. 
Innovative studies over the past ten years have led to a next-generation bactericidal approach which acts through physico-mechanical means. The typical size of an individual bacterium is on the order of $1 \mu \mathrm{m}$, with much of its cellular components in the nanoscale range. These components and their biological functions have proven to be greatly influenced when contact is made with other nanoscale materials in their environment [11-13]. Certain nanoscale structures and geometries have unique abilities of inhibiting, injuring, or even lethally inactivating a bacterial cell upon contact. The lattermost of these materials, henceforth known as "mechano-bactericidal nanostructures," can be prepared as dispersed nanoparticles suspended in media, referred to as colloids, or fabricated as surface nanotopography (Figure 1). Mechano-bactericidal colloids and mechano-bactericidal nanotopographies are seldom compared despite new colloidal insights potentially being beneficial to those studying nanotopography, and vice versa. This review bridges the knowledge gap between the two strategies of mechano-bactericidal nanostructures. By doing so, we hope to illuminate existing themes and offer potential research directions for the future.

The immediate advantage of mechano-bactericidal nanostructures over traditional, chemicalbased antibacterial agents stems from their physical interactions with bacteria. As they are not designed to release antibacterial compounds, aforementioned drawbacks associated with diffusion losses are not of primary concern. However, their non-diffusive design is also the primary limitation in their potential application, as they can only inactivate bacteria that have made direct contact with the mechano-bactericidal nanostructures. Ideally, the most effective antibacterial surface would instantly eliminate adhered cells before proliferation can occur [14]. In general, this has been the case for substrates featuring mechano-bactericidal nanostructures. In particular, nanostructures designed with 
sharper and higher aspect ratio geometries have been shown to rapidly eliminate adhered bacteria within mere minutes of contact. The focus herein lies in the mechano-bactericidal mechanisms of action upon such contact. Proof-of-concept demonstrations by pioneering research groups are also highlighted. The fabrication techniques to produce nanoscale colloids versus topographies are vastly different from one another and therefore described here only in brief, as we focus on the lethal interactions between bacteria and mechano-bactericidal nanostructures.

\section{Nanodarts and nanoblades as mechano-bactericidal colloids}

In this section, we introduce suspended colloids that act as mechano-bactericidal nanostructures. Current knowledge of such colloids is mostly limited to studies of carbon nanotubes (CNTs) and graphene materials. Comprehensive reviews on the fabrication of CNTs $[15,16]$ or graphene $[17,18]$ as well as their biological interactions are available but do not emphasize the mechano-bactericidal mechanisms discussed herein. Conventional antibacterial assays $[19,20]$ demonstrate the mechano-bactericidal activity of these colloidal nanostructures under typical incubation conditions, whereas computational simulations offer insights into underlying biological interaction between an individual colloid and a model cell membrane lipid bilayer.

\subsection{CNTs as nanodarts}

In 2007, Elimelech et al. reported the first direct evidence of the mechano-bactericidal mode of action: single walled carbon nanotubes (SWCNTs) were demonstrated to severely pierce and damage the cell membrane of Escherichia coli as a result of direct contact, hinting at the potential of 
SWCNTs as antibacterial materials [21]. In their study, metal toxicity and oxidative stress were ruled out due to the pristine nature of the preparation. In contrast, studies with multi-walled CNTs (MWCNTs) showed that, compared to aggregates of SWCNTs, bactericidal efficacy by aggregates of MWCNT were not as pronounced, but that direct contact between E. coli cells and CNTs was necessary for inactivation in both cases $[22,23]$. Leakage of genetic material following cell membrane destruction was quantified, as were levels of stress factor-associated mRNA gene products. Both experiments once again pointed to the superior antibacterial efficacy of SWCNTs. Their results suggest that direct contact due to the high aspect ratio geometry of SWCNTs was primarily responsible for the bactericidal effect. Furthermore, higher specific surface area of SWCNTs enable more interaction opportunities with membranes of cells compared to MWCNTs, leading to increased occurrences of membrane piercing events by the ends of nanotubes [22]. Similarly, Chen $e t$ al. found thin and rigid SWCNTs induced more significant piercing, needle-like damage to the membranes of gut bacteria than MWCNTs [24].

Liu et al. increased the antibacterial contact area available by preparing pristine and individually dispersed, one-dimensional (1D) SWCNTs $8.3 \AA$ in diameter. They concluded that these SWCNTs primarily act as "nanodarts" to pierce bacterial cells, while cell death due to inhibitory effects of oxidative stress and toxic impurities were minimal [25]. Increased antibacterial rates were achievable simply by changing the shaking speed of the flasks during incubation with SWCNTs, thereby increasing the frequency and intensity delivered via the mechano-bactericidal SWCNTs. The group evaluated survival of both Gram-positive (Bacillus subtilis and Staphylococcus aureus) and Gramnegative (E. coli and Pseudomonas aeruginosa) bacteria and found SWCNTs exhibited higher 
antibacterial activity toward Gram-positive cells. They reasoned that the natural complexity of Gramnegative bacteria (characterized by inner and outer membranes sandwiching a peptidoglycan layer) made it harder for nanodarts to penetrate. The presence of complex appendages and functional groups protruding from the outer membrane of Gram-negative bacteria possibly acts as a shielding layer akin to steric hindrance, lessening the direct impact and interaction between colloidal nanostructures and Gram-negative bacteria. The same group later used a sharp $2 \mathrm{~nm}$ atomic force microscope (AFM) tip to mimic an individual collision event between a cell and a SWCNT and found that a singular collision between a CNT and a cell is insufficient to induce lethal damage. Instead, antibacterial activity would require the cumulative effect of a large number of individually dispersed nanodart-membrane interactions over time [26]. Table 1 lists representative studies attributing bacterial cell death to the direct physical interactions with CNTs.

On the one hand, experimental assays evaluate efficacy of mechano-bactericidal nanostructures in conventional incubation conditions to monitor bacterial proliferation. However, direct observations in these studies are limited to the use of microscopy at static time points that offer only discrete glimpses of the process. Simulation techniques, on the other hand, offer more comprehensive explanations as to how nanomaterials interact with modeled cell membranes, albeit modeling efforts investigate lipid bilayer membranes and cannot represent the complexities of a bacterial membrane with a peptidoglycan cell wall and cellular appendages. The model of choice for the majority of simulations is coarse grained molecular dynamics, which combines a cluster of atoms, molecules, or chemical groups into one particle to reduce computational cost [28, 29]. Through modeling, Yang $e t$ al. established that penetrating capability of anisotropic nanoparticles across a lipid bilayer is 
determined by the contact area between the particle and bilayer. For this reason, penetration becomes more difficult when the possible contact area of cylindrical nanoparticles increases [30]. Simulations of individual interactions of a CNT with a cell's lipid bilayer membrane are generally in agreeance that a CNT would first enter a cell through either ends of the tube structure, likely in a near-perpendicular manner [31-35]. For instance, Wallace et al. used steered molecular dynamics to pull a SWCNT through a lipid bilayer, finding less pulling force was required when orientation of the SWCNT was perpendicular to the bilayer compared to a parallel orientation [33]. After initial insertion, additional destructive intermolecular interactions with lipid molecules would arise, leading to lipids being extracted from the rest of the bilayer, for instance, or the formation of lipid micelles [34]. Figure 2 shows a selection of SEM images highlighting destruction of cell membranes by CNTs as well as modeling experiments investigating a singular membrane insertion event of a SWCNT.

Mechano-bactericidal penetration does not fully explain the observed antibacterial effect of CNTs. The energy required for a CNT to fully and spontaneously penetrate through a membrane is quite high $[36,37]$, not to mention other nanoscale interactions are also at play. Through modeling and experimentation, it is known that engineered nanomaterials can interact with the bacterial cell membrane by adsorbing onto the membrane, passing through it, extracting its lipids, inducing pore formation, or activating membrane receptor proteins [38-41]. Like most other antibacterial nanomaterials, CNTs offer numerous antibacterial interactions depending on their design parameters and environmental influences [42-44]. Pasquini et al. found SWCNTs functionalized with chemical moieties that compacted CNT aggregates indirectly decreased cytotoxicity [45]. Vecitis et al. suggested that piercing is merely the first of three steps leading to CNTs' overall antibacterial mechanism. The 
second step being the perturbation of the rest of the cell membrane, followed by the third and last step of CNT structure-dependent bacterial oxidation [44].

\subsection{Graphene sheets as nanoblades}

Aside from CNTs, another class of colloidal suspensions frequently reported to physically induce cell damage is graphene nanomaterials - truly two-dimensional (2D) sheet-like nanomaterials consisting of a single layer of carbon atoms arranged hexagonally. For the purposes of this review, graphene, its derivatives (such as graphene oxide (GO)), and other chemically-modified graphene nanosheet structures are broadly referred to as graphene family nanomaterials (GFNs). As GFNs are also high aspect ratio, low-dimensional nanomaterials, they were predicted to share certain antibacterial mechanisms observed in CNTs [46]. Akhavan et al. laid GO "nanowalls" on stainless steel substrates via electrophoretic deposition; the randomly oriented GO nanosheets, some of which were nearly perpendicular with respect to the substrate, provided sharp edges on the surface available for bacterial interaction [46]. E. coli and S. aureus were used as Gram-negative and Gram-positive bacterial models, respectively. Nanowalls exhibited stronger antibacterial activities against $S$. aureus as shown by colony forming unit (CFU) enumeration and quantification of cytoplasmic RNA leakage. The group reasoned that the lack of outer membrane in Gram-positive bacteria made it more sensitive to the direct contact with the sharp edges of nanowalls, echoing the increased antibacterial susceptibility of Gram-positive bacteria to mechano-bactericidal colloids previously observed with 
CNTs [46]. In elucidating how GFNs interact with cell membranes, Lu et al. magnetically aligned GO nanosheets in a vertical orientation with respect to the substrate, finding the vertical orientation to exhibit enhanced antibacterial activity against E. coli compared to random and horizontal orientations [47]. Based on the limited generation of reactive oxygen species (ROS), they attributed antibacterial properties to a combination of direct electron transfer and nanosheet penetration due to the increased density of edges of the vertically aligned GO. Liu et al. found that sharp edges of GFNs induce significant membrane stress towards E. coli [48], comparable to earlier mechano-bactericidal studies involving sharp SWCNTs. Experimental observations by other groups concluded that efflux or leakage of intracellular genetic material was further evidence for mechanical disruption of bacterial membranes by graphene, GO, and reduced GO [27, 49-52].

Computational simulations confirmed this hypothesized membrane interaction mechanism, commonly reported as "insertion mode" or "penetration mode" [53-59]. Li et al. used coarse-grained molecular dynamics and all-atom molecular dynamics to reveal that membrane piercing by GFN blade-like (or knife-like) materials is initiated at rough asperities, or sharp corners, of the graphene sheets [53]. A comprehensive study by $\mathrm{Tu}$ et al. experimentally assessed membrane damage of $E$. coli by dispersed GO, then revealed via simulations that GO can spontaneously insert through different methods of entry into both the outer and inner E. coli membranes [54]. Table 2 lists representative studies attributing bacterial cell death to direct physical insertion with GFNs.

However, the edge-first penetration of GFNs leading to their mechano-bactericidal action is not unanimously accepted; investigation into the physical interactions with GFNs is further complicated by the orientation of nanosheets upon contact, the density of edges, degree of asperities, 
and GFN size. These factors combined with theoretical modeling suggest that GFNs perhaps act more than as a simple blade [60]. Researchers have shown, for example, that by destructively extracting membrane lipids, the basal plane of GO contributes more significantly to overall bactericidal properties than the blade-like penetration mechanism [61, 62]. Mangadlao et al. eliminated edge penetration effects by immobilizing flat GO sheets whose edges were embedded in a poly(ethylene terephthalate) (PET) substrate [63]. This surface still inactivated E. coli, indicating that mechanobactericidal mechanisms may not contribute major antibacterial activity and that lateral dimension of nanosheets must be taken into account. The insertion, penetration, or "nanoblade" mechanobactericidal mode of action represents one of a handful of mechanisms frequently reported in the interaction of GFNs with biological materials. Other commonly reported antibacterial mechanisms that act simultaneously upon contact include oxidative stress initiated by ROS or by charge transfer. For instance, Perreault et al. found that oxidative stress of GO was also size-dependent such that smaller GO sheets were more antimicrobial due to their high defect density [64]. Chong et al. showed light-induced oxidative stress accelerates electron transfer from bacterial biomolecules to the surface of GO, resulting in the reduction of GO while also causing cell destruction [65]. Pore formation induced by GFNs, which leads to osmotic imbalance and subsequent cell death is also possible [66].

It is clear that the extent to which the mechano-bactericidal activity contributes to overall antibacterial efficacy is still contested [60, 67-69]. Size-dependency also influences membrane interactions, as GFNs are nearly atomically thin in one dimension but the other two dimensions are typically large [53]. Through simulations, Dallavalle et al. suggested through molecular dynamics modeling that small sheets with a high degree of asperities tend to pierce membranes with ease, whereas 
intermediate-sized sheets require optimal orientation and larger sheets were more likely to sit flat atop membranes [55]. Instead of piercing, these larger GFNs would instead adsorb on the membrane causing upturning of the phospholipid molecules. Figure 3 provides depictions of some GFNmembrane interactions. Experimentally, size-dependent interactions have focused on mammalian cell culture as opposed to bacterial systems. For instance, Sanchez et al. [17] suggests a critical lateral dimension to be approximately $5 \mu \mathrm{m}$ in mammalian cell interactions with GFNs. Few-layer-graphene smaller than that can readily insert through the eukaryotic cell membranes and become internalized by human macrophages, whereas the cells would adsorb and wrap around larger graphene sheets. Whether this could lead to inflammation following mammalian uptake of GFNs is unknown [17]. These insights offer a glimpse into how mechano-bactericidal colloids would impact human health, which must be evaluated before deployment.

\subsection{Other colloidal mechano-bactericidal nanostructures}

In areas of research where nanomaterials interact with biological components, such as cell membranes, the terms nanoknife and nanoblade are used interchangeably to describe graphene materials to provide imagery for the edge-first insertion mechanism and 2D graphene nanosheet itself. The use of nanodart to describe mechano-bactericidal carbon nanotubes appears to be limited in literature, and thus far specifically refers to CNTs. Comparisons with other 1D materials would confirm whether the nanodart effect is a ubiquitous trait across all 1D nanomaterials. For instance, only one published computational simulation of cellular interactions with boron nitride nanotubes (BNNTs) exists [70]. According to this study, spontaneous insertion of BNNTs (considered to be more stable and inert than CNTs) into the lipid membrane can occur but the nanotube could stay 
within the bilayer without further disruption. Early investigations into yet other nanoparticles have indicated physico-mechanical interactions at play. For example, Penders et al. evaluated gold nanoparticles of similar sizes but of different shapes and concluded that spheres did not cause antibacterial activity. Rather, nanoflowers possessed shape-dependent antibacterial activity but were innocuous towards mammalian cell behavior [71]. Similarly, copper oxide nanoparticles and nanosheets with irregular edges were shown by Gilbertson et al. to possess physical and chemical toxicity [72]. The nanosheets would orient parallel to the cell membrane, suggesting bactericidal interaction to originate from rotation.

Lastly, CNTs and GFNs represent mechano-bactericidal colloids for which a strong body of knowledge exists on their fabrication and geometric modification. Current lack of understanding prevents the conclusive claim of mechano-bactericidal efficacy for other colloids. It is worth noting that early applications employing these CNTs and GFNs did not have antibacterial applications in mind $[21,73,74]$. Rather, their mechanical, electronic, and structural properties allowed diverse uses which eventually overlapped into biological and microbiological research. As others have pointed out, substances categorized as $1 \mathrm{D}$ - or $2 \mathrm{D}$ - or $2 \mathrm{D}$ layered-nanomaterials, both naturally occurring or synthetic, are expansive $[13,75]$. Other nanomaterials that are atomically thin and possess high aspect ratio exist as well (e.g., chalcogenide nanosheets such as tungsten disulfide or molybdenum disulfide or exfoliated bismuth selenide, etc.). It is reasonable to hypothesize that these under-represented nanomaterials too have the potential to deliver mechano-antibacterial efficacy but simply have yet to be explored in this context. In doing so, however, researchers should be wary of the presence of 
impurities, which are often difficult to eliminate but need to be accounted for in any antibacterial experiments.

\section{Nanopillars and nanospikes as mechano-bactericidal nanotopographies}

The first mechano-bactericidal nanotopography described in literature was of natural origin [76]. Since then, a handful of other natural surfaces have demonstrated similar mechano-bactericidal activity, inspiring biomimetic efforts to replicate these surfaces on artificial substrates. Here, we summarize research efforts in mechano-bactericidal nanotopographies and their proposed modes of action to highlight established concepts as well as questions that remain. For additional reading, Elbourne et al. [5] recently prepared a comprehensive review of antibacterial surfaces.

\subsection{Mechano-bactericidal nanotopographies in nature}

Ivanova et al. were the first to report a surface lethal to bacterial cells purely through mechanical means [76], retroactively referring to this mechanism as mechano-bactericidal [77-80]. The title of this review borrows the same terminology. The nanostructured surface in question was the wing of the cicada insect Psaltoda claripennis, which possesses a topography consisting of spherically capped nanopillars. Electron microscopy of the cicada wing revealed spherically capped nanopillars $200 \mathrm{~nm}$ tall with a $100 \mathrm{~nm}$ wide base that tapered off to $60 \mathrm{~nm}$ at the cap with ordered periodicity of $170 \mathrm{~nm}$ between the center of two pillars [76]. P. aeruginosa cells that adhered to the wing's nanotopography were rapidly killed independent of surface chemistry - a factor which was ruled out after wings sputtercoated with $10 \mathrm{~nm}$ of gold maintained the same bactericidal efficacy. 
Wings of several species of cicada, dragonfly, as well as damselfly have been discovered to possess mechano-bactericidal nanopillar or nanospike topographies (Table 3 summarizes the reports of natural mechano-bactericidal surfaces to date). It is hypothesized that the bactericidal activity of these insect wings represents an evolutionary function to prevent accumulation of microbial matter such as biofilms, thereby maintaining the insects' lightweight stature during flight $[76,81,82]$. Curiously, the skin of gecko lizards is bactericidal in the same manner because of their nanotipped hairs termed spinules [83-85], suggesting evolutionary convergence. SEM by Watson $e$ al. revealed individual spinules of the skin of the gecko Lucasium steindachneri to be $4 \mu \mathrm{m}$ long with slight curvature and spherically capped with radius of 10-30 nm. Since exposure to moisture (which carry microorganisms) or environmental contaminants in their habitat is continuous and unavoidable, geckos likely possess self-cleaning and mechano-bactericidal nanotopography as a protective mechanical barrier [85]. Figure 4 showcases some natural mechano-bactericidal surfaces such as cicada wing, dragonfly wing, and gecko skin.

\subsection{Topographical geometry influences mechano-bactericidal efficacy}

Hasan $e t$ al. found the nanopillar topography of the $P$. claripennis cicada wing to be highly efficient against Gram-negative bacteria (P. aeruginosa, E. coli, Pseudomonas fluorescens, Branhamella catarrhalis). It appears that bacteria initially sank down onto the wing nanotopography, spread between nanopillars, then suddenly experienced a short downward displacement, as detected by AFM, indicative of lethal rupture of the cell. Most attached cells were killed in this manner in under 5 minutes [76]. However, the same wing was not particularly effective against Gram-positive species ( $B$. subtilis, S. aureus, Planococcus maritimus) [86]. Thus, bacterial cell wall and outer membrane were 
suggested to play decisive roles in the cell-surface interaction. It is well-known that, compared to Gram-negative species, Gram-positive bacteria have characteristically thick peptidoglycan layers, generating more rigid, stress-bearing outer surfaces $[86,88]$.

Pogodin et al. performed biophysical simulations of Gram-negative and Gram-positive bacteria and their interactions with nanopillars to show that it is the region of the cell membrane stretched between two neighboring nanopillars that leads to critical rupture [87]. Importantly, cells are not pierced directly as was the case with SWCNTs described in the previous section. Rather, Gramnegative cells adhered to the nanopillar surface and critically deformed and were ultimately killed by the nanopillars of the wing. In contrast, morphology of Gram-positive cells was largely unchanged and remained viable due to their increased rigidity. It appears the thicker cell wall of Gram-positive bacteria would require greater deformational stress than what the cicada nanopillars can inflict. Other simulations were largely in agreeance, suggesting that Gram-negative cell death was thermodynamically possible on nanopillars whereas the geometry needs optimization to rupture Gram-positive bacteria $[89,90]$. There is discrepancy in proposed approaches to optimize the nanopillar geometry. Simulations by Li et al. called for increasing nanopillar distribution density, the radius and the height of nanopillars to enhance the adhesion contact area available for critical stretching [90]. Meanwhile, Xue et al. suggested sharper nanopillars with increased spacing would result in the increased bacterial membrane surface tension necessary for Gram-positive rupture [89]. Experimental results from Fisher et al. agreed with the latter approach, finding sharp diamond nanocones on silicon substrate arranged in a non-uniform array of decreased distribution density were more bactericidal towards $P$. aeurignosa compared to uniformly arranged, high density nanocones [91]. 
In contrast, Linklater $e t$ al. and Kelleher et al., assessing silicon nanopillars and cicada wing nanopillars respectively, found densely packed nanopillars to be more bactericidal [79, 92]. Dickson et al. fabricated nanopillars constructed of poly(methyl methacrylate) (PMMA) of varying periodicity. Their findings indicate optimal nanopillar spacing lies between 130 and $380 \mathrm{~nm}$ against $E$. coli proliferation, whereas periodicity of $600 \mathrm{~nm}$ caused noticeably less cell death [93]. The optimal spacing to produce the most bactericidal nanotopography remains unclear and under investigation.

Nonetheless, it is generally unanimous in literature that increasing the height and sharpness of the nanopillars, thereby enhancing the aspect ratio, improves bactericidal efficacy. This notion was definitively demonstrated by Ivanova et al. [94]. Biomimicking dragonfly wings, which possessed longer pillars with sharper tips, the group fabricated longer, sharper, high aspect ratio pillars with black silicon (referred to as "nanospikes") via reactive-ion etching. Nanospikes were 20-80 nm in diameter with height of $500 \mathrm{~nm}$ and randomly distributed and were able to achieve increased cell wall stress resulting in bactericidal efficacy against Gram-negative and Gram-positive bacteria. Even highly resilient $B$. subtilis endospores were killed at a rate of $-140,000$ spores per minute per $\mathrm{cm}^{2}$ [94]. Thus, despite not directly piercing bacterial cells, enhancement of the aspect ratio of nanopillars and nanospikes results in greater mechano-bactericidal efficacy, mirroring the trend of sharper CNTs and thinner GFNs discussed above also being more effective. In this case, longer and sharper nanospikes provide the necessary deformation and stress to the highly rigid cell walls of Gram-positive bacteria and endospores.

\subsection{Bacterial motility can influence mechano-bactericidal efficacy}


There is evidence to suggest bacterial motility, rather than cell rigidity, plays the determining role in bactericidal action. Bandara et al. assessed bactericidal nanopillars of dragonfly wings and observed that dead adhered cells leaked cytoplasmic material which appeared characteristically flattened [81]. Observations with helium ion microscopy showed cell death soon after attachment. At this point, membrane wrinkling and beginning of cytoplasm leakage was also observed. Upon initial attachment, cell morphology appeared flattened and finally, cytoplasm completely leaked and the cell sank into the nanopillars causing loss of cell integrity. However, rather than cells being critically stretched between two pillars, cell death was attributed to the combination of high adhesive force between pillars and the extracellular polymeric substances (EPS) on the exterior of bacterial cells as well as the strong shear forces generated as adhered bacteria - still alive at this point - push, pull, and struggle upon the unfavorable topography that cause cell death [81]. Diu et al. assessed three highly motile bacteria ( $P$. aeruginosa, E. coli, and B. subtilis) and three low- or non-motile species (S. aureus, Enterococcus faecalis, and Klebsiella pneumonia) on a titanium substrate covered with titania nanowires [95]. Their observations implicate motility as the determining factor: significant bactericidal activities occurred for motile bacteria whereas little or negligible activity was observed for low-motility bacteria. This explanation corroborates well with conclusions made by Kelleher $e t$ al. [92], who established that the greater number of nanostructures with which cells come into contact, the greater the bactericidal activity, as motility along the surface naturally introduces more contact. In relation to motility, Sengstock et al. proposed that cell division during bacterial proliferation could explain the observed difference in antibacterial activity between E. coli and S. aureus [96]. Namely, E. coli multiply by elongating, which requires horizontal movement of the cell body attached to the nanostructures. In 
contrast, $S$. aureus divide along three planes, resulting in some daughter cells clustering above the original cells thus escaping direct contact with the nanostructured surface [97].

The physico-mechanical forces of cicada nanopillars have also shown lethality against the eukaryotic microorganism Saccharomyces cerevisiae (yeast) [98], hinting at broad-spectrum efficacy against microorganisms in general. Despite inherent differences in yeast cell wall structure, ruptured yeast cells resembled the morphology of ruptured bacteria others have reported. Observations of "puddles" were reported and hypothesized to derive from leaked yeast cytoplasm. Notably, these findings raise doubts over motility being the primary mechanism behind microbial cell death since $S$. cerevisiae cells do not possess propulsion mechanisms and are considered non-motile. It is also wholly possible that cell wall rigidity as well as motility, whether through movement or cell division, play combined roles in cell death but the influence of each factor is not well understood.

\subsection{Biomimetic and bio-inspired nanotopographies}

In addition to insect wings and gecko skin, biomimetic artificial nanotopography constructed from silicon, titanium, PMMA, biopolymer blends, gold, and diamond have also demonstrated mechano-bactericidal efficacy. Collectively, works described in this section emphasize mechanobactericidal nanostructures as antibacterial agents independent of chemistry. As is true for their natural counterparts, the spacing between two adjacent structures as well as the aspect ratio of the structures of an artificial nanotopography are critical factors in antibacterial efficacy. Spacing dictates the number of nanostructures an adhered cell is subjected to, as well as the degree of deformation experienced by the membrane regions between adjacent nanostructures, while enhancing the aspect ratio of 
nanotopography features leads to higher mechano-bactericidal efficiency. Table 4 summarizes experimental studies describing natural as well as biomimetic mechano-bactericidal topographies. After bacterial incubation with mechano-bactericidal nanotopography, a trend among these studies is the characteristically flattened or sunken cell morphology observed by SEM, sometimes accompanied by visible puddles of cytoplasmic leakage and loss of cell integrity.

For artificial biomimetic nanotopography, black silicon nanospikes pioneered by Ivanova et al. have made the most progress in demonstrating applicability. To date, the black silicon nanospikes from Ivanova et al. represents the only mechano-bactericidal nanotopography that has also proven in vivo biocompatibility [99]. Implanting the black silicon substrate in mice showed that the nanostructured surface produced minor tissue reaction, whereas a smooth, nontextured silicon induced a greater inflammatory reaction. Black silicon nanospikes have undoubtedly shown great promise but the use of silicon is scarce in biomedical applications due to its brittle nature. As titanium materials are heavily favored for implants, mechano-bactericidal titanium substrates hold a more promising future but these have not been evaluated in vivo. The possibility of irritation or inflammation as a result of mechano-bactericidal titania nanowires $[95,100]$, for example, needs to be addressed.

\subsection{Tissue cell interactions with mechano-bactericidal nanotopographies}


Most cells in human tissues (aside from blood cells) are anchorage-dependent and are influenced by surface topography [110]. Anchorage and subsequent mammalian tissue healing and regeneration can be promoted through the patterning of nanotopography. In fact, implant surfaces are sometimes nanoroughened intentionally for this very reason $[111,112]$. Thus, there potentially exists an elusive "sweet-spot" that maximizes tissue cell growth while minimizing bacterial proliferation. To that end, Ivanova et al. pre-infected the black silicon nanospike substrate with pathogenic bacteria, then seeded with monkey kidney tissue cells. The substrate was able to inhibit bacterial proliferation while simultaneously promoting tissue growth [99]. A handful of other nanotopographies have also demonstrated selective inhibition of bacteria while also supporting eukaryotic cell growth $[85,95,96$, $100,104,105]$. These findings are of particular importance as they show that on an optimally engineered implant surface, tissue cells can win what is known as "the race for the surface" [113]. In brief, the race describes the onset of surface colonization of an implant material. If initially won out predominantly by host tissue cells, the implant will be protected from invading pathogens, allowing tissue integration to proceed. However, if initial bacterial colonization dominates over host tissue, severe inflammatory response leading to subsequent biofilm infection symptoms would arise, which would require explant and additional surgical efforts $[113,114]$. Figure 5 depicts several biomimetic mechano-bactericidal nanotopography, some of which selectively inhibition bacteria while supporting eukaryotic cell growth.

Why are nanopillar and nanospike topographies consistently lethal against bacterial cells yet capable of supporting tissue growth? Rigidity (and flexibility) of cell membranes is perhaps the critical difference. Compared to eukaryotes, bacteria are typically more rigid due to the prokaryotic 
peptidoglycan layer rendering bacterial cells incapable of accommodating the nanotopographies described in this section [12]. Hanson et al. used transmission electron microscopy to show that eukaryotic cells are capable of stretching and distorting to accommodate the shape of the nanopillars without compromising intracellular material [115]. Xu et al. fabricated high aspect ratio, hollow alumina nanostraws (100 $\mathrm{nm}$ in diameter, $1 \mathrm{~mm}$ in height) bound to a polycarbonate substrate. They determined penetration of Chinese hamster ovary cells sitting atop the surface by the nanostraws as a relatively rare occurrence - approximately 1 in 15 nanostraws induced penetration [116]. Similarly, fibroblast cells on an array of gallium phosphide vertical nanowires $(3.9 \mu \mathrm{m}$ height, 4 nanowires per $\mu \mathrm{m}^{2}$ ) akin to a "bed-of-nails" were fully motile, resided on top of the nanowires, and were morphologically similar to cells on control substrates [117]. Xie et al. modeled cell adhesion on an array of nanowires, concluding nanowire geometry and cell stiffness as critical factors [118]. Moreover, stiffer eukaryotic cells are more sensitive as a result of high stress concentration at the nanowire tips, thus the penetration force required is low. While their study did not extend to prokaryotes, their conclusions help to explain the high bactericidal efficiency of nanotopography due to the stiff peptidoglycan layer in bacteria. However, by that logic, Gram-positive bacteria with thicker peptidoglycans would be more sensitive to mechano-bactericidal nanotopography, which is not the case experimentally. 


\section{Future outlook}

Collectively, the research community commands immense knowledge over nanofabrication techniques. Only a small handful of these techniques have been applied to mechano-bactericidal materials so far. In anticipation of an influx of work in this field of antibacterial research, we urge researchers to report or tabulate all available measurements of their nanostructures' dimensions. This is especially important since there is no consensus in terminology of reported nanostructures. For example, a "nanospike" topography carries connotation and imagery of sharper, higher aspect ratio protrusions compared to a "nanopillar" topography but no systematic categorization exists to distinguish the two. Moreover, neither of the two terms can convey height or periodicity, critical factors related to efficacy of a mechano-bactericidal nanotopography. Similarly, lateral size of atomically thin GFNs influence their interactions with cell membranes but the term "nanoknife" cannot express this property.

The very nature of mechano-bactericidal colloids in their dispersed form means they are unfortunately impractical in certain applications. Furthermore, their discharge can be harmful to the environment and to human health. CNTs, GFNs, and engineered nanomaterials in general can enter the body via skin penetration, inhalation, ingestion, or biomedical implantation [17]. Gilbertson et al. asserted that the bactericidal properties of dispersed CNTs can be a benefit or a hazardous liability depending on their intended use $[45,119,120]$. Immobilization of these colloids onto surfaces would open future possibilities while minimizing their dispersal. Indeed, we note a recent shift in the 
literature from studying bacterial interactions with dispersed CNTs to the incorporation of these nanomaterials in filters for water purification. Recent advances in antifouling filtration membranes are reviewed in Werber et al. [121] and Zhang et al. [122]. Immobilizing mechano-bactericidal colloids blurs the line between bactericidal mechanisms of colloids versus mechanisms of nanotopography, which makes knowledge exchange between researchers studying these two systems even more important. It is reasonable to suggest that membrane-piercing interactions of CNTs can be retained even as they are surface-immobilized but efficacy and contribution of mechano-bactericidal activity to the overall antibacterial activity observed would likely change as a result.

For mechano-bactericidal nanotopographies, highly ordered fabrication is not trivial but Nowlin $e t$ al. have recently outlined a set of useful lithography techniques [123]. Once constructed, their use becomes attractive as they are easy to manipulate, more predictable and more effective than release-based approaches to controlling both bacterial and eukaryotic cell growth [112]. Medicallyrelevant mechano-bactericidal prototypes constructed from PMMA or titanium offer great promise. Abiotic devices intended to interface with the human body (e.g., catheters or intravenous injection ports) are frequently infected and in need of constant replacement, and could perhaps benefit most from what mechano-bactericidal nanotopography has to offer. The design of the urinary catheter, for example, has remained the same since the 1930s and while antibacterial coatings reduce the risk of catheter-associated urinary tract infections, the efficacy cannot be maintained [124]. Applying mechano-bactericidal nanotopography on the inner surface of the catheter could prove highly effective. An elegant microfluidic design by Wang et al. using black silicon nanospikes as a substrate demonstrates that mechano-bactericidal nanotopography can function even under fluid flow [101]. 
In any case, how human cells interact and remodel in the presence of the same nanotopography still needs to be understood.

Whether a surface is directly patterned with mechano-bactericidal nanotopography, or if it is prepared by immobilizing mechano-bactericidal colloids, their practical limitation is the same. Namely, only bacteria that have made direct contact with the surface interface will be inactivated. In other words, they can prevent bacterial proliferation on the surface of interest but cannot sterilize the bulk environment surrounding the surface. Conversely, as antibacterial surfaces that do not release chemicals, mechano-bactericidal nanostructures offer opportunities to develop sustainable antimicrobial materials. Black silicon nanospikes, for example, cannot be consumed metabolically nor are they lost through diffusion. Thus, if the surface is not damaged, mechano-bactericidal materials can be reused indefinitely when cleaned. The same can be said for surface-immobilized mechanobactericidal colloids. Thus far, no reports on the cleaning and reuse of mechano-bactericidal materials have been published. It is safe to say that the cleaning regiment must consistently remove surface fouling in the form of adsorbed macromolecules (e.g., proteins, polysaccharides), accumulated dead bacteria or debris at no detriment to the mechano-bactericidal nanostructures.

Lastly, to truly harness its sustainable potential, we suggest an exciting area of research resides in the reproduction of nanostructures onto natural biopolymers. Cellulose and chitin are the first and second most abundant biopolymers, respectively $[125,126]$. Both are sourced from renewable origins; cellulose is sourced from plant matter while chitin is extracted from insect or crustacean exoskeletons [127]. Interestingly, the wings of the cicada insect, the inspiration that prompted all subsequent mechano-bactericidal nanotopographies to date, is composed mainly of chitin [76, 128]. Considerable 
efforts have already been made in the fabrication of bioactive substrates composed of cellulose and chitin [129-132]. Both these biopolymers have long been explored as drug delivery substrates and tissue engineering scaffolds [133-135] and could incorporate mechano-bactericidal nanotopography as a new function. Constructing antibacterial topographies onto such biodegradable, nontoxic, tuneable biopolymer films extracted directly from renewable resources would further improve the sustainable outlook of mechano-bactericidal materials.

\section{Concluding perspectives}

Mechano-bactericidal colloids and mechano-bactericidal nanotopography differ from one another in terms of the specific mechanism(s) of physical damage. 1D, 2D, or near-2D colloidal materials are so thin that they pierce and slice bacterial cell membranes thereby lethally compromising membrane integrity and causing membrane destruction. Compared to Gram-negative bacteria, it seems the less complicated cell membranes of Gram-positive bacteria (which lack outer membranes as well as membrane-associated proteins) causes them to be more susceptible to mechano-bactericidal effects of CNTs and GFNs. For CNTs specifically, the thinner in diameter and higher the aspect ratio, the stronger the antibacterial properties. The same trend is true for GFNs featuring higher degrees of sharp edge-asperities. Conversely, the mechanism of action for a surface topography of nanopillars is hypothesized to be very different. Although under debate, there is evidence to suggest lethal shear forces stemming from motility of certain bacteria species or movement atop the nanotopography associated with cells that struggle. Another explanation is that regions of cell membranes perched 
between two pillars experience deformation leading to critical membrane stress and cell rupture. Since Gram-positive cells have stiffer peptidoglycan layers, they were not critically deformed by mechanobactericidal nanotopography until enhanced aspect ratio of nanospikes was achieved.

Thus, in both colloids and nanotopography, increasing the aspect ratio by creating sharper or thinner nanostructures improves antibacterial efficacy. In either case, cell morphology observable via SEM appears flattened with loss of integrity accompanied by leakage of cytoplasmic matter. Since mechano-bactericidal rely heavily on said morphology observations, preparations of bacterial samples for SEM should strongly consider the use of critical point drying (CPD). Air-drying, which almost all mechano-bactericidal reports have employed, leads to distortion of the cells under observation that could be misconstrued as effects of mechano-bactericidal nanostructures. CPD is widely recognized as the most correct method to observe biological samples as it causes the least amount of alterations to the cell morphology under investigation $[136,137]$.

Studies to date have favored a select few Gram-positive and Gram-negative bacterial models while other infectious microorganisms of interest such as fungi or even viruses have not been adequately assessed. Investigations of these microorganisms with known mechano-bactericidal materials would establish their efficacy as broad-spectrum antimicrobials while providing insight in the exact role of the stiff peptidoglycan layer and by extension, the role of the cell membrane. Indeed, many other differences exist between Gram-positive and Gram-negative cells. The presence (or absence) of outer surface proteins and other biomacromolecules such as lipopolysaccharides could play a role. The difference in thickness of the peptidoglycan between Gram-positive and Gram-negative bacteria is likely insufficient to fully encompass the mechano-bactericidal interactions. Even within 
Gram-positive bacteria, peptidoglycan thickness is not uniform - the peptidoglycan of $E$. coli is nearly three times thicker than that of $P$. aeruginosa despite both being Gram-negative bacteria [138].

A comprehensive understanding of the underlying interactions between biological systems and mechano-bactericidal nanostructures must be well established before widespread application. Their environmental fate and transformation when discharged must also be considered. Toxic reagents or byproducts during synthesis of certain nanomaterials will need to be evaluated as well. No doubt, the ideal scenario is one in which risk towards health and safety is minimized while antibacterial efficacy is maximized. At this moment, the mechanism of action of colloidal mechano-bactericidal systems and its consequence on bacterial cell-surface interactions remain confounding. The same can be said for mechano-bactericidal nanotopography. Fully understanding the bacterial interactions with mechanobactericidal nanostructures in the future will help define optimal geometry and dimensions. Finally, design of these nanomaterials must conform to the principles of green chemistry [139] in order to accelerate their deployment as next-generation antibacterial products. 


\section{Acknowledgements}

The authors thank A. Valiei, V. Maisuria, N. Yousefi, and C. King for helpful discussions. This research was undertaken, in part, thanks to funding from the Canada Excellence Research Chairs Program (RDR), the Canada Research Chairs Program (NT, CM), the NSERC Discovery Program (RDR and NT) and the Eugenie Ulmer Lamothe fund at McGill University (NL).

\section{Conflicts of interest}

The authors declare no competing conflicts of interest. 


\section{References}

[1] Hasan J, Crawford RJ, Ivanova EP. Antibacterial surfaces: the quest for a new generation of biomaterials. Trends Biotechnol. 2013;31:295-304. http://dx.doi.org/10.1016/j.tibtech.2013.01.017.

[2] Lewis K, Klibanov AM. Surpassing nature: rational design of sterile-surface materials. Trends Biotechnol. 2005;23:343-8. https://doi.org/10.1016/j.tibtech.2005.05.004.

[3] Andersson DI, Hughes D. Microbiological effects of sublethal levels of antibiotics. Nat Rev Micro. 2014;12:465-78. http://dx.doi.org/10.1038/nrmicro3270.

[4] Cloutier M, Mantovani D, Rosei F. Antibacterial coatings: challenges, perspectives, and opportunities. Trends Biotechnol. 2015;33:637-52. https://doi.org/10.1016/j.tibtech.2015.09.002.

[5] Elbourne A, Crawford RJ, Ivanova EP. Nano-structured antimicrobial surfaces: From nature to synthetic analogues. J Colloid Interface Sci. 2017;508:603-16. https://doi.org/10.1016/j.jcis.2017.07.021.

[6] Blair JM, Webber MA, Baylay AJ, Ogbolu DO, Piddock LJ. Molecular mechanisms of antibiotic resistance. Nat Rev Microbiol. 2015;13:42-51. http://dx.doi.org/10.1038/nrmicro3380.

[7] Perros M. A sustainable model for antibiotics. Science. 2015;347:1062-4. http://dx.doi.org/10.1126/science.aaa3048.

[8] Banerjee I, Pangule RC, Kane RS. Antifouling coatings: recent developments in the design of surfaces that prevent fouling by proteins, bacteria, and marine organisms. Adv Mater. 2011;23:690-718. http://dx.doi.org/10.1002/adma.201001215.

[9] Tuson HH, Weibel DB. Bacteria-surface interactions. Soft Matter. 2013;9:4368-80.

http://dx.doi.org/10.1039/C3SM27705D.

[10] Lejeune P. Contamination of abiotic surfaces: what a colonizing bacterium sees and how to blur it. Trends Microbiol. 2003;11:179-84. http://dx.doi.org/10.1016/S0966-842X(03)00047-7.

[11] Bazaka K, Crawford RJ, Ivanova EP. Do bacteria differentiate between degrees of nanoscale surface roughness? Biotechnol J. 2011;6:1103-14. http://dx.doi.org/10.1002/biot.201100027.

[12] Anselme K, Davidson P, Popa A, Giazzon M, Liley M, Ploux L. The interaction of cells and bacteria with surfaces structured at the nanometre scale. Acta Biomater. 2010;6:3824-46. https://doi.org/10.1016/j.actbio.2010.04.001.

[13] Wang Z, Zhu W, Qiu Y, Yi X, von dem Bussche A, Kane A, et al. Biological and environmental interactions of emerging two-dimensional nanomaterials. Chem Soc Rev. 2016;45:1750-80. http://dx.doi.org/10.1039/C5CS00914F. [14] Rizzello L, Galeone A, Vecchio G, Brunetti V, Sabella S, Pompa PP. Molecular response of Escherichia coli adhering onto nanoscale topography. Nanoscale Res Lett. 2012;7:1. http://dx.doi.org/10.1186/1556-276X-7-575. [15] Smith SC, Rodrigues DF. Carbon-based nanomaterials for removal of chemical and biological contaminants from water: a review of mechanisms and applications. Carbon. 2015;91:122-43.

https://doi.org/10.1016/j.carbon.2015.04.043.

[16] Johnston HJ, Hutchison GR, Christensen FM, Peters S, Hankin S, Aschberger K, et al. A critical review of the biological mechanisms underlying the in vivo and in vitro toxicity of carbon nanotubes: The contribution of physicochemical characteristics. Nanotoxicology. 2010;4:207-46. http://dx.doi.org/10.3109/17435390903569639.

[17] Sanchez VC, Jachak A, Hurt RH, Kane AB. Biological Interactions of Graphene-Family Nanomaterials: An Interdisciplinary Review. Chemical Res Toxicol. 2012;25:15-34. http://dx.doi.org/10.1021/tx200339h.

[18] Mao HY, Laurent S, Chen W, Akhavan O, Imani M, Ashkarran AA, et al. Graphene: promises, facts, opportunities, and challenges in nanomedicine. Chem Rev. 2013;113:3407-24. http://dx.doi.org/10.1021/cr300335p.

[19] Seil JT, Webster TJ. Antimicrobial applications of nanotechnology: methods and literature. Int J Nanomedicine. 2012;7:2767-81. http://dx.doi.org/10.2147/IJN.S24805.

[20] Reller LB, Weinstein M, Jorgensen JH, Ferraro MJ. Antimicrobial Susceptibility Testing: A Review of General Principles and Contemporary Practices. Clin Infect Dis. 2009;49:1749-55. http://dx.doi.org/10.1086/647952.

[21] Kang S, Pinault M, Pfefferle LD, Elimelech M. Single-walled carbon nanotubes exhibit strong antimicrobial activity. Langmuir. 2007;23:8670-3. http://dx.doi.org/10.1021/la701067r.

[22] Kang S, Herzberg M, Rodrigues DF, Elimelech M. Antibacterial effects of carbon nanotubes: size does matter! Langmuir. 2008;24:6409-13. http://dx.doi.org/10.1021/la800951v. 
[23] Kang S, Mauter MS, Elimelech M. Physicochemical determinants of multiwalled carbon nanotube bacterial cytotoxicity. Environ Sci Technol. 2008;42:7528-34. http://dx.doi.org/10.1021/es8010173.

[24] Chen H, Wang B, Gao D, Guan M, Zheng L, Ouyang H, et al. Broad-Spectrum Antibacterial Activity of Carbon Nanotubes to Human Gut Bacteria. Small. 2013;9:2735-46. http://dx.doi.org/10.1002/smll.201202792.

[25] Liu S, Wei L, Hao L, Fang N, Chang MW, Xu R, et al. Sharper and faster "nano darts" kill more bacteria: a study of antibacterial activity of individually dispersed pristine single-walled carbon nanotube. ACS Nano. 2009;3:3891-902. http://dx.doi.org/10.1021/nn901252r.

[26] Liu S, Ng AK, Xu R, Wei J, Tan CM, Yang Y, et al. Antibacterial action of dispersed single-walled carbon nanotubes on Escherichia coli and Bacillus subtilis investigated by atomic force microscopy. Nanoscale. 2010;2:2744-50. http://dx.doi.org/10.1039/c0nr00441c.

[27] Wang X, Liu X, Han H. Evaluation of antibacterial effects of carbon nanomaterials against copper-resistant Ralstonia solanacearum. Colloids Surf B Biointerfaces. 2013;103:136-42.

http://dx.doi.org/10.1016/j.colsurfb.2012.09.044.

[28] Wu L, Jiang X. Recent developments in methodology employed to study the interactions between nanomaterials and model lipid membranes. Anal Bioanal Chem. 2016;408:2743-58. http://dx.doi.org/10.1007/s00216-015-9157-5.

[29] Jimenez-Cruz CA, Kang S-g, Zhou R. Large scale molecular simulations of nanotoxicity. Wiley Interdiscip Rev Syst Biol Med. 2014;6:329-43. http://dx.doi.org/10.1002/wsbm.1271.

[30] Yang K, Ma Y-Q. Computer simulation of the translocation of nanoparticles with different shapes across a lipid bilayer. Nat Nanotechnol. 2010;5:579-83. http://dx.doi.org/10.1038/nnano.2010.141.

[31] Shi X, Kong Y, Gao H. Coarse grained molecular dynamics and theoretical studies of carbon nanotubes entering cell membrane. Acta Mechanica Sinica. 2008;24:161-9. https://doi.org/10.1007/s10409-007-0131-0.

[32] Shi X, von dem Bussche A, Hurt RH, Kane AB, Gao H. Cell entry of one-dimensional nanomaterials occurs by tip recognition and rotation. Nat Nanotechnol. 2011;6:714-9. http://dx.doi.org/doi:10.1038/nnano.2011.151.

[33] Wallace EJ, Sansom MS. Blocking of carbon nanotube based nanoinjectors by lipids: a simulation study. Nano Lett. 2008;8:2751-6. http://dx.doi.org/10.1021/nl801217f.

[34] Lelimousin M, Sansom MS. Membrane perturbation by carbon nanotube insertion: pathways to internalization. Small. 2013;9:3639-46. http://dx.doi.org/10.1002/smll.201202640.

[35] Kraszewski S, Bianco A, Tarek M, Ramseyer C. Insertion of short amino-functionalized single-walled carbon nanotubes into phospholipid bilayer occurs by passive diffusion. PLoS One. 2012;7:e40703.

https://doi.org/10.1371/journal.pone.0040703.

[36] Yaron PN, Holt BD, Short PA, Lösche M, Islam MF, Dahl KN. Single wall carbon nanotubes enter cells by endocytosis and not membrane penetration. J Nanobiotechnol. 2011;9:45. https://doi.org/10.1186/1477-3155-9-45.

[37] Pogodin S, Baulin VA. Can a Carbon Nanotube Pierce through a Phospholipid Bilayer? ACS Nano. 2010;4:5293300. http://dx.doi.org/10.1021/nn1016549.

[38] Negoda A, Liu Y, Hou W-C, Corredor C, Moghadam BY, Musolff C, et al. Engineered nanomaterial interactions with bilayer lipid membranes: screening platforms to assess nanoparticle toxicity. Int J of Biomed Nanosci and Nanotechnol. 2013;3:52-83. https://doi.org/10.1504/IJBNN.2013.054512.

[39] Moghadam BY, Hou W-C, Corredor C, Westerhoff P, Posner JD. Role of Nanoparticle Surface Functionality in the Disruption of Model Cell Membranes. Langmuir. 2012;28:16318-26. http://dx.doi.org/10.1021/la302654s.

[40] Suresh AK, Pelletier DA, Doktycz MJ. Relating nanomaterial properties and microbial toxicity. Nanoscale. 2013;5:463-74. http://dx.doi.org/10.1039/C2NR32447D.

[41] Wang L, Hu C, Shao L. The antimicrobial activity of nanoparticles: present situation and prospects for the future. Int J Nanomedicine. 2017;12:1227-49. http://dx.doi.org/10.2147/IJN.S121956.

[42] Holt BD, Dahl KN, Islam MF. Cells take up and recover from protein-stabilized single-wall carbon nanotubes with two distinct rates. ACS Nano. 2012;6:3481-90. http://dx.doi.org/10.1021/nn300504x.

[43] Arias LR, Yang L. Inactivation of Bacterial Pathogens by Carbon Nanotubes in Suspensions. Langmuir.

2009;25:3003-12. http://dx.doi.org/10.1021/la802769m.

[44] Vecitis CD, Zodrow KR, Kang S, Elimelech M. Electronic-Structure-Dependent Bacterial Cytotoxicity of SingleWalled Carbon Nanotubes. ACS Nano. 2010;4:5471-9. http://dx.doi.org/10.1021/nn101558x. 
[45] Pasquini LM, Hashmi SM, Sommer TJ, Elimelech M, Zimmerman JB. Impact of Surface Functionalization on Bacterial Cytotoxicity of Single-Walled Carbon Nanotubes. Environ Sci Technol. 2012;46:6297-305.

http://dx.doi.org/10.1021/es300514s.

[46] Akhavan O, Ghaderi E. Toxicity of graphene and graphene oxide nanowalls against bacteria. ACS Nano. 2010;4:5731-6. http://dx.doi.org/10.1021/nn101390x.

[47] Lu X, Feng X, Werber JR, Chu C, Zucker I, Kim J-H, et al. Enhanced antibacterial activity through the controlled alignment of graphene oxide nanosheets. Proc Natl Acad Sci USA. 2017. http://dx.doi.org/10.1073/pnas.1710996114.

[48] Liu S, Zeng TH, Hofmann M, Burcombe E, Wei J, Jiang R, et al. Antibacterial activity of graphite, graphite oxide, graphene oxide, and reduced graphene oxide: membrane and oxidative stress. ACS Nano. 2011;5:6971-80.

http://dx.doi.org/10.1021/nn202451x.

[49] Musico YLF, Santos CM, Dalida MLP, Rodrigues DF. Surface modification of membrane filters using graphene and graphene oxide-based nanomaterials for bacterial inactivation and removal. ACS Sustainable Chem Eng. 2014;2:1559-65. http://dx.doi.org/10.1021/sc500044p.

[50] Chen J, Peng H, Wang X, Shao F, Yuan Z, Han H. Graphene oxide exhibits broad-spectrum antimicrobial activity against bacterial phytopathogens and fungal conidia by intertwining and membrane perturbation. Nanoscale.

2014;6:1879-89. http://dx.doi.org/10.1039/c3nr04941h.

[51] Chen J, Wang X, Han H. A new function of graphene oxide emerges: inactivating phytopathogenic bacterium Xanthomonas oryzae pv. Oryzae. J Nanopart Res. 2013;15:1-14. https://doi.org/10.1007/s11051-013-1658-6.

[52] He J, Zhu X, Qi Z, Wang C, Mao X, Zhu C, et al. Killing dental pathogens using antibacterial graphene oxide. ACS Appl Mater Interfaces. 2015;7:5605-11. http://dx.doi.org/10.1021/acsami.5b01069.

[53] Li Y, Yuan H, von dem Bussche A, Creighton M, Hurt RH, Kane AB, et al. Graphene microsheets enter cells through spontaneous membrane penetration at edge asperities and corner sites. Proc Natl Acad Sci USA.

2013;110:12295-300. http://dx.doi.org/10.1073/pnas.1222276110.

[54] Tu Y, Lv M, Xiu P, Huynh T, Zhang M, Castelli M, et al. Destructive extraction of phospholipids from

Escherichia coli membranes by graphene nanosheets. Nat Nanotechnol. 2013;8:594-601.

http://dx.doi.org/10.1038/nnano.2013.125.

[55] Dallavalle M, Calvaresi M, Bottoni A, Melle-Franco M, Zerbetto F. Graphene can wreak havoc with cell membranes. ACS Appl Mater Interfaces. 2015;7:4406-14. http://dx.doi.org/10.1021/am508938u.

[56] Wang J, Wei Y, Shi X, Gao H. Cellular entry of graphene nanosheets: the role of thickness, oxidation and surface adsorption. RSC Adv. 2013;3:15776-82. http://dx.doi.org/10.1039/C3RA40392K.

[57] Titov AV, Král P, Pearson R. Sandwiched graphene- membrane superstructures. ACS Nano. 2009;4:229-34. http://dx.doi.org/10.1021/nn9015778.

[58] Guo R, Mao J, Yan L-T. Computer simulation of cell entry of graphene nanosheet. Biomaterials. 2013;34:4296301. https://doi.org/10.1016/j.biomaterials.2013.02.047.

[59] Luan B, Huynh T, Zhao L, Zhou R. Potential Toxicity of Graphene to Cell Functions via Disrupting ProteinProtein Interactions. ACS Nano. 2015;9:663-9. http://dx.doi.org/10.1021/nn506011j.

[60] Zou X, Zhang L, Wang Z, Luo Y. Mechanisms of the antimicrobial activities of graphene materials. J Am Chem Soc. 2016;138:2064-77. http://dx.doi.org/10.1021/jacs.5b11411.

[61] Hui L, Piao J-G, Auletta J, Hu K, Zhu Y, Meyer T, et al. Availability of the basal planes of graphene oxide determines whether it is antibacterial. ACS Appl Mater Interfaces. 2014;6:13183-90.

http://dx.doi.org/10.1021/am503070z.

[62] Yi X, Gao H. Cell interaction with graphene microsheets: near-orthogonal cutting versus parallel attachment. Nanoscale. 2015;7:5457-67. http://dx.doi.org/10.1039/c4nr06170e.

[63] Mangadlao JD, Santos CM, Felipe MJL, de Leon ACC, Rodrigues DF, Advincula RC. On the antibacterial mechanism of graphene oxide (GO) Langmuir-Blodgett films. Chem Commun. 2015;51:2886-9.

http://dx.doi.org/10.1039/C4CC07836E.

[64] Perreault F, de Faria AF, Nejati S, Elimelech M. Antimicrobial Properties of Graphene Oxide Nanosheets: Why Size Matters. ACS Nano. 2015;9:7226-36. http://dx.doi.org/10.1021/acsnano.5b02067. 
[65] Chong Y, Ge C, Fang G, Wu R, Zhang H, Chai Z, et al. Light-Enhanced Antibacterial Activity of Graphene Oxide, Mainly via Accelerated Electron Transfer. Environ Sci Technol. 2017;51:10154-61.

http://dx.doi.org/10.1021/acs.est.7b00663.

[66] Pham VTH, Truong VK, Quinn MDJ, Notley SM, Guo Y, Baulin VA, et al. Graphene Induces Formation of Pores That Kill Spherical and Rod-Shaped Bacteria. ACS Nano. 2015;9:8458-67.

http://dx.doi.org/10.1021/acsnano.5b03368.

[67] Soroush A, Rice D, Rahaman MS, Perreault F. Antimicrobial Properties of Graphene Nanomaterials: Mechanisms and Applications. Graphene-based Materials in Health and Environment: Springer; 2016. p. 287-322.

https://doi.org/10.1007/978-3-319-45639-3_10.

[68] Palmieri V, Papi M, Conti C, Ciasca G, Maulucci G, De Spirito M. The future development of bacteria fighting medical devices: the role of graphene oxide. Expert Rev Med. 2016;13:1013-9.

http://dx.doi.org/10.1080/17434440.2016.1245612.

[69] Ji H, Sun H, Qu X. Antibacterial applications of graphene-based nanomaterials: Recent achievements and challenges. Adv Drug Deliv Rev. 2016;105:176-89. https://doi.org/10.1016/j.addr.2016.04.009.

[70] Thomas M, Enciso M, Hilder TA. Insertion Mechanism and Stability of Boron Nitride Nanotubes in Lipid Bilayers. J Phys Chem B. 2015;119:4929-36. http://dx.doi.org/10.1021/acs.jpcb.5b00102.

[71] Penders J, Stolzoff M, Hickey DJ, Andersson M, Webster TJ. Shape-dependent antibacterial effects of noncytotoxic gold nanoparticles. Int J Nanomedicine. 2017;12:2457. http://dx.doi.org/10.2147/IJN.S124442.

[72] Gilbertson LM, Albalghiti EM, Fishman ZS, Perreault F, Corredor C, Posner JD, et al. Shape-Dependent Surface Reactivity and Antimicrobial Activity of Nano-Cupric Oxide. Environ Sci Technol. 2016;50:3975-84.

http://dx.doi.org/10.1021/acs.est.5b05734.

[73] Allen MJ, Tung VC, Kaner RB. Honeycomb carbon: a review of graphene. Chem Rev. 2009;110:132-45.

http://dx.doi.org/10.1021/cr900070d.

[74] De Volder MFL, Tawfick SH, Baughman RH, Hart AJ. Carbon Nanotubes: Present and Future Commercial

Applications. Science. 2013;339:535-9. http://dx.doi.org/10.1126/science.1222453.

[75] Xu M, Liang T, Shi M, Chen H. Graphene-like two-dimensional materials. Chem Rev. 2013;113:3766-98. http://dx.doi.org/10.1021/cr300263a.

[76] Ivanova EP, Hasan J, Webb HK, Truong VK, Watson GS, Watson JA, et al. Natural bactericidal surfaces: mechanical rupture of Pseudomonas aeruginosa cells by cicada wings. Small. 2012;8:2489-94.

http://dx.doi.org/10.1002/smll.201200528.

[77] Ivanova EP, Crawford RJ. Antibacterial Surfaces: Springer; 2015. http://dx.doi.org/10.1007/978-3-319-18594-1.

[78] Nguyen DH, Pham VT, Al Kobaisi M, Bhadra C, Orlowska A, Ghanaati S, et al. Adsorption of Human Plasma

Albumin and Fibronectin onto Nanostructured Black Silicon Surfaces. Langmuir. 2016;32:10744-51.

http://dx.doi.org/10.1021/acs.langmuir.6b02601.

[79] Linklater DP, Nguyen HKD, Bhadra CM, Juodkazis S, Ivanova EP. Influence of nanoscale topology on bactericidal efficiency of black silicon surfaces. Nanotechnology. 2017;28:245301. http://dx.doi.org/10.1088/1361-6528/aa700e.

[80] Truong VK, Geeganagamage NM, Baulin VA, Vongsvivut J, Tobin MJ, Luque P, et al. The susceptibility of Staphylococcus aureus CIP 65.8 and Pseudomonas aeruginosa ATCC 9721 cells to the bactericidal action of nanostructured Calopteryx haemorrhoidalis damselfly wing surfaces. Appl Microbiol Biotechnol. 2017:1-8. http://dx.doi.org/10.1007/s00253-017-8205-9.

[81] Bandara CD, Singh S, Afara IO, Tesfamichael T, Wolff A, Ostrikov K, et al. Bactericidal Effects of Natural Nanotopography of Dragonfly Wing on Escherichia coli. ACS Appl Mater Interfaces. 2017.

http://dx.doi.org/10.1021/acsami.6b13666.

[82] Mainwaring DE, Nguyen SH, Webb H, Jakubov T, Tobin M, Lamb RN, et al. The nature of inherent bactericidal activity: insights from the nanotopology of three species of dragonfly. Nanoscale. 2016;8:6527-34.

http://dx.doi.org/10.1039/C5NR08542J.

[83] Li X, Cheung GS, Watson GS, Watson JA, Lin S, Schwarzkopf L, et al. The nanotipped hairs of gecko skin and biotemplated replicas impair and/or kill pathogenic bacteria with high efficiency. Nanoscale. 2016;8:18860-9.

http://dx.doi.org/10.1039/C6NR05046H. 
[84] Green DW, Lee KK-H, Watson JA, Kim H-Y, Yoon K-S, Kim E-J, et al. High Quality Bioreplication of Intricate Nanostructures from a Fragile Gecko Skin Surface with Bactericidal Properties. Sci Rep. 2017;7.

http://dx.doi.org/10.1038/srep41023.

[85] Watson GS, Green DW, Schwarzkopf L, Li X, Cribb BW, Myhra S, et al. A gecko skin micro/nano structure-A low adhesion, superhydrophobic, anti-wetting, self-cleaning, biocompatible, antibacterial surface. Acta Biomater. 2015;21:109-22. http://dx.doi.org/10.1016/j.actbio.2015.03.007.

[86] Hasan J, Webb HK, Truong VK, Pogodin S, Baulin VA, Watson GS, et al. Selective bactericidal activity of nanopatterned superhydrophobic cicada Psaltoda claripennis wing surfaces. Appl Microbiol Biotechnol. 2013;97:925762. http://dx.doi.org/10.1007/s00253-012-4628-5.

[87] Pogodin S, Hasan J, Baulin Vladimir A, Webb Hayden K, Truong Vi K, Phong Nguyen The H, et al. Biophysical Model of Bacterial Cell Interactions with Nanopatterned Cicada Wing Surfaces. Biophys J. 2013;104:835-40.

10.1016/j.bpj.2012.12.046.

[88] Filloux A, Whitfield C. Editorial: The many wonders of the bacterial cell surface. FEMS Microbiol Rev. 2016;40:161-3. http://dx.doi.org/10.1093/femsre/fuv047.

[89] Xue F, Liu J, Guo L, Zhang L, Li Q. Theoretical study on the bactericidal nature of nanopatterned surfaces. J Theor Biol. 2015;385:1-7. http://dx.doi.org/10.1016/j.jtbi.2015.08.011.

[90] Li X. Bactericidal mechanism of nanopatterned surfaces. Phys Chem Chem Phys. 2016;18:1311-6. http://dx.doi.org/10.1039/c5cp05646b.

[91] Fisher LE, Yang Y, Yuen M-F, Zhang W, Nobbs AH, Su B. Bactericidal activity of biomimetic diamond nanocone surfaces. Biointerphases. 2016;11:011014. http://dx.doi.org/10.1116/1.4944062.

[92] Kelleher SM, Habimana O, Lawler J, O’Reilly B, Daniels S, Casey E, et al. Cicada wing surface topography: An investigation into the bactericidal properties of nanostructural features. ACS Appl Mater Interfaces. 2015;8:14966-74. http://dx.doi.org/10.1021/acsami.5b08309.

[93] Dickson MN, Liang EI, Rodriguez LA, Vollereaux N, Yee AF. Nanopatterned polymer surfaces with bactericidal properties. Biointerphases. 2015;10:021010. http://dx.doi.org/10.1116/1.4922157.

[94] Ivanova EP, Hasan J, Webb HK, Gervinskas G, Juodkazis S, Truong VK, et al. Bactericidal activity of black silicon. Nat Commun. 2013;4. http://dx.doi.org/10.1038/ncomms3838.

[95] Diu T, Faruqui N, Sjöström T, Lamarre B, Jenkinson HF, Su B, et al. Cicada-inspired cell-instructive nanopatterned arrays. Sci Rep. 2014;4:7122. http://dx.doi.org/10.1038/srep07122.

[96] Sengstock C, Lopian M, Motemani Y, Borgmann A, Khare C, Buenconsejo PJS, et al. Structure-related antibacterial activity of a titanium nanostructured surface fabricated by glancing angle sputter deposition.

Nanotechnology. 2014;25:195101. http://dx.doi.org/10.1088/0957-4484/25/19/195101.

[97] Tzagoloff H, Novick R. Geometry of cell division in Staphylococcus aureus. J Bacteriol. 1977;129:343-50.

[98] Nowlin K, Boseman A, Covell A, LaJeunesse D. Adhesion-dependent rupturing of Saccharomyces cerevisiae on biological antimicrobial nanostructured surfaces. J R Soc Interface. 2015;12:20140999.

http://dx.doi.org/10.1098/rsif.2014.0999.

[99] Pham VT, Truong VK, Orlowska A, Ghanaati S, Barbeck M, Booms P, et al. "Race for the surface": eukaryotic cells can win. ACS Appl Mater Interfaces. 2016;8:22025-31. http://dx.doi.org/10.1021/acsami.6b06415.

[100] Tsimbouri P, Fisher L, Holloway N, Sjostrom T, Nobbs A, Meek RD, et al. Osteogenic and bactericidal surfaces from hydrothermal titania nanowires on titanium substrates. Sci Rep. 2016;6. http://dx.doi.org/10.1038/srep36857.

[101] Wang X, Bhadra CM, Dang THY, Buividas R, Wang J, Crawford RJ, et al. A bactericidal microfluidic device constructed using nano-textured black silicon. RSC Adv. 2016;6:26300-6. http://dx.doi.org/10.1039/C6RA03864F. [102] Vassallo E, Pedroni M, Silvetti T, Morandi S, Toffolatti S, Angella G, et al. Bactericidal performance of nanostructured surfaces by fluorocarbon plasma. Mater Sci Eng C Mater Biol Appl. 2017;80:117-21. http://dx.doi.org/10.1016/j.msec.2017.05.111.

[103] Sjöström T, Nobbs AH, Su B. Bactericidal nanospike surfaces via thermal oxidation of Ti alloy substrates. Mater Lett. 2016;167:22-6. https://doi.org/10.1016/j.matlet.2015.12.140.

[104] Bhadra CM, Truong VK, Pham VT, Al Kobaisi M, Seniutinas G, Wang JY, et al. Antibacterial titanium nanopatterned arrays inspired by dragonfly wings. Sci Rep. 2015;5:16817. http://dx.doi.org/10.1038/srep16817. 
[105] Hasan J, Jain S, Chatterjee K. Nanoscale Topography on Black Titanium Imparts Multi-biofunctional Properties for Orthopedic Applications. Sci Rep. 2017;7:41118. http://dx.doi.org/10.1038/srep41118.

[106] Wu S, Zuber F, Brugger J, Maniura-Weber K, Ren Q. Antibacterial Au nanostructured surfaces. Nanoscale. 2016;8:2620-5. http://dx.doi.org/10.1039/C5NR06157A.

[107] May P, Clegg M, Silva T, Zanin H, Fatibello-Filho O, Celorrio V, et al. Diamond-coated 'black silicon' as a promising material for high-surface-area electrochemical electrodes and antibacterial surfaces. J Mater Chem B. 2016;4:5737-46. http://dx.doi.org/10.1039/C6TB01774F.

[108] Zou F, Zhou H, Jeong DY, Kwon J, Eom SU, Park TJ, et al. Wrinkled Surface-Mediated Antibacterial Activity of Graphene Oxide Nanosheets. ACS Appl Mater Interfaces. 2017;9:1343-51. http://dx.doi.org/10.1021/acsami.6b15085.

[109] Yuan Y, Zhang Y. Enhanced biomimic bactericidal surfaces by coating with positively-charged ZIF nano-dagger arrays. Nanomedicine. 2017;13:2199-077. http://dx.doi.org/10.1016/j.nano.2017.06.003.

[110] Chan B, Leong K. Scaffolding in tissue engineering: general approaches and tissue-specific considerations. Eur Spine J. 2008;17:467-79. http://dx.doi.org/10.1007/s00586-008-0745-3.

[111] Luong-Van E, Rodriguez I, Low HY, Elmouelhi N, Lowenhaupt B, Natarajan S, et al. Review: Micro-and nanostructured surface engineering for biomedical applications. J Mater Res. 2013;28:165-74.

https://doi.org/10.1557/jmr.2012.398.

[112] Jeon H, Simon CG, Kim G. A mini-review: cell response to microscale, nanoscale, and hierarchical patterning of surface structure. J Biomed Mater Res B Appl Biomater. 2014;102:1580-94. http://dx.doi.org/10.1002/jbm.b.33158.

[113] Gristina A, Naylor P, Myrvik Q. Infections from biomaterials and implants: a race for the surface. Med Prog Technol. 1987;14:205-24.

[114] Busscher HJ, Van Der Mei HC, Subbiahdoss G, Jutte PC, Van Den Dungen JJ, Zaat SA, et al. Biomaterialassociated infection: locating the finish line in the race for the surface. Sci Transl Med. 2012;4:153rv10.

http://dx.doi.org/10.1126/scitranslmed.3004528.

[115] Hanson L, Lin ZC, Xie C, Cui Y, Cui B. Characterization of the cell-nanopillar interface by transmission electron microscopy. Nano Lett. 2012;12:5815-20. http://dx.doi.org/10.1021/nl303163y.

[116] Xu AM, Aalipour A, Leal-Ortiz S, Mekhdjian AH, Xie X, Dunn AR, et al. Quantification of nanowire penetration into living cells. Nat Commun. 2014;5:3613. http://dx.doi.org/10.1038/ncomms4613.

[117] Persson H, Li Z, Tegenfeldt JO, Oredsson S, Prinz CN. From immobilized cells to motile cells on a bed-of-nails: effects of vertical nanowire array density on cell behaviour. Sci Rep. 2015;5:18535.

http://dx.doi.org/10.1038/srep18535.

[118] Xie X, Xu AM, Angle MR, Tayebi N, Verma P, Melosh NA. Mechanical model of vertical nanowire cell penetration. Nano Lett. 2013;13:6002-8. http://dx.doi.org/10.1021/nl403201a.

[119] Gilbertson LM, Goodwin DG, Taylor AD, Pfefferle L, Zimmerman JB. Toward Tailored Functional Design of Multi-Walled Carbon Nanotubes (MWNTs): Electrochemical and Antimicrobial Activity Enhancement via Oxidation and Selective Reduction. Environ Sci Technol. 2014;48:5938-45. http://dx.doi.org/10.1021/es500468y.

[120] Gilbertson LM, Melnikov F, Wehmas LC, Anastas PT, Tanguay RL, Zimmerman JB. Toward safer multi-walled carbon nanotube design: establishing a statistical model that relates surface charge and embryonic zebrafish mortality.

Nanotoxicology. 2016;10:10-9. http://dx.doi.org/10.3109/17435390.2014.996193.

[121] Werber JR, Osuji CO, Elimelech M. Materials for next-generation desalination and water purification membranes. Nat Rev Microbiol. 2016;1:16018. http://dx.doi.org/10.1038/natrevmats.2016.18.

[122] Zhang R, Liu Y, He M, Su Y, Zhao X, Elimelech M, et al. Antifouling membranes for sustainable water purification: strategies and mechanisms. Chem Soc Rev. 2016;45:5888-924. http://dx.doi.org/10.1039/C5CS00579E.

[123] Nowlin K, LaJeunesse DR. Fabrication of hierarchical biomimetic polymeric nanostructured surfaces. Mol Syst Des Eng. 2017;2:201-13. http://dx.doi.org/10.1039/C7ME00009J.

[124] Feneley RCL, Hopley IB, Wells PNT. Urinary catheters: history, current status, adverse events and research agenda. J Med Eng Technol. 2015;39:459-70. http://dx.doi.org/10.3109/03091902.2015.1085600.

[125] O'sullivan AC. Cellulose: the structure slowly unravels. Cellulose. 1997;4:173-207.

https://doi.org/10.1023/A:1018431705579.

[126] Tharanathan RN, Kittur FS. Chitin - The Undisputed Biomolecule of Great Potential. Critical reviews in food science and nutrition. 2003;43:61-87. http://dx.doi.org/10.1080/10408690390826455. 
[127] Younes I, Rinaudo M. Chitin and chitosan preparation from marine sources. Structure, properties and applications. Mar Drugs. 2015;13:1133-74. http://dx.doi.org/10.3390/md13031133.

[128] Chandran R, Williams L, Hung A, Nowlin K, LaJeunesse D. SEM characterization of anatomical variation in chitin organization in insect and arthropod cuticles. Micron. 2016;82:74-85.

http://dx.doi.org/10.1016/j.micron.2015.12.010.

[129] Turner MB, Spear SK, Holbrey JD, Rogers RD. Production of bioactive cellulose films reconstituted from ionic liquids. Biomacromolecules. 2004;5:1379-84. http://dx.doi.org/10.1021/bm049748q.

[130] Qin Y, Lu X, Sun N, Rogers RD. Dissolution or extraction of crustacean shells using ionic liquids to obtain high molecular weight purified chitin and direct production of chitin films and fibers. Green Chem. 2010;12:968-71.

http://dx.doi.org/10.1039/C003583A.

[131] Swatloski RP, Spear SK, Holbrey JD, Rogers RD. Dissolution of cellose with ionic liquids. J Am Chem Soc. 2002;124:4974-5. http://dx.doi.org/10.1021/ja025790m.

[132] King C, Shamshina JL, Gurau G, Berton P, Khan NFAF, Rogers RD. A platform for more sustainable chitin films from an ionic liquid process. Green Chem. 2017;19:117-26. http://dx.doi.org/10.1039/C6GC02201D.

[133] Muzzarelli RA. Chitins and chitosans for the repair of wounded skin, nerve, cartilage and bone. Carbohydr Polym. 2009;76:167-82. https://doi.org/10.1016/j.carbpol.2008.11.002.

[134] Khor E, Lim LY. Implantable applications of chitin and chitosan. Biomaterials. 2003;24:2339-49.

https://doi.org/10.1016/S0142-9612(03)00026-7.

[135] Müller FA, Müller L, Hofmann I, Greil P, Wenzel MM, Staudenmaier R. Cellulose-based scaffold materials for cartilage tissue engineering. Biomaterials. 2006;27:3955-63. https://doi.org/10.1016/j.biomaterials.2006.02.031.

[136] Fischer ER, Hansen BT, Nair V, Hoyt FH, Dorward DW. Scanning Electron Microscopy. Current Protocols in Microbiology: John Wiley \& Sons, Inc.; 2005. http://dx.doi.org/10.1002/9780471729259.mc02b02s25.

[137] Bray D. Critical Point Drying of Biological Specimens for Scanning Electron Microscopy. In: Williams JR,

Clifford AA, (editors). Supercritical Fluid Methods and Protocols. Totowa, NJ: Humana Press; 2000. p. 235-43.

http://dx.doi.org/10.1385/1-59259-030-6:235.

[138] Matias VR, Al-Amoudi A, Dubochet J, Beveridge TJ. Cryo-transmission electron microscopy of frozen-hydrated sections of Escherichia coli and Pseudomonas aeruginosa. J Bacteriol. 2003;185:6112-8.

http://dx.doi.org/10.1128/JB.185.20.6112-6118.2003.

[139] Gilbertson LM, Zimmerman JB, Plata DL, Hutchison JE, Anastas PT. Designing nanomaterials to maximize performance and minimize undesirable implications guided by the Principles of Green Chemistry. Chem Soc Rev. 2015;44:5758-77. http://dx.doi.org/10.1039/C4CS00445K. 


\section{FIGURES}

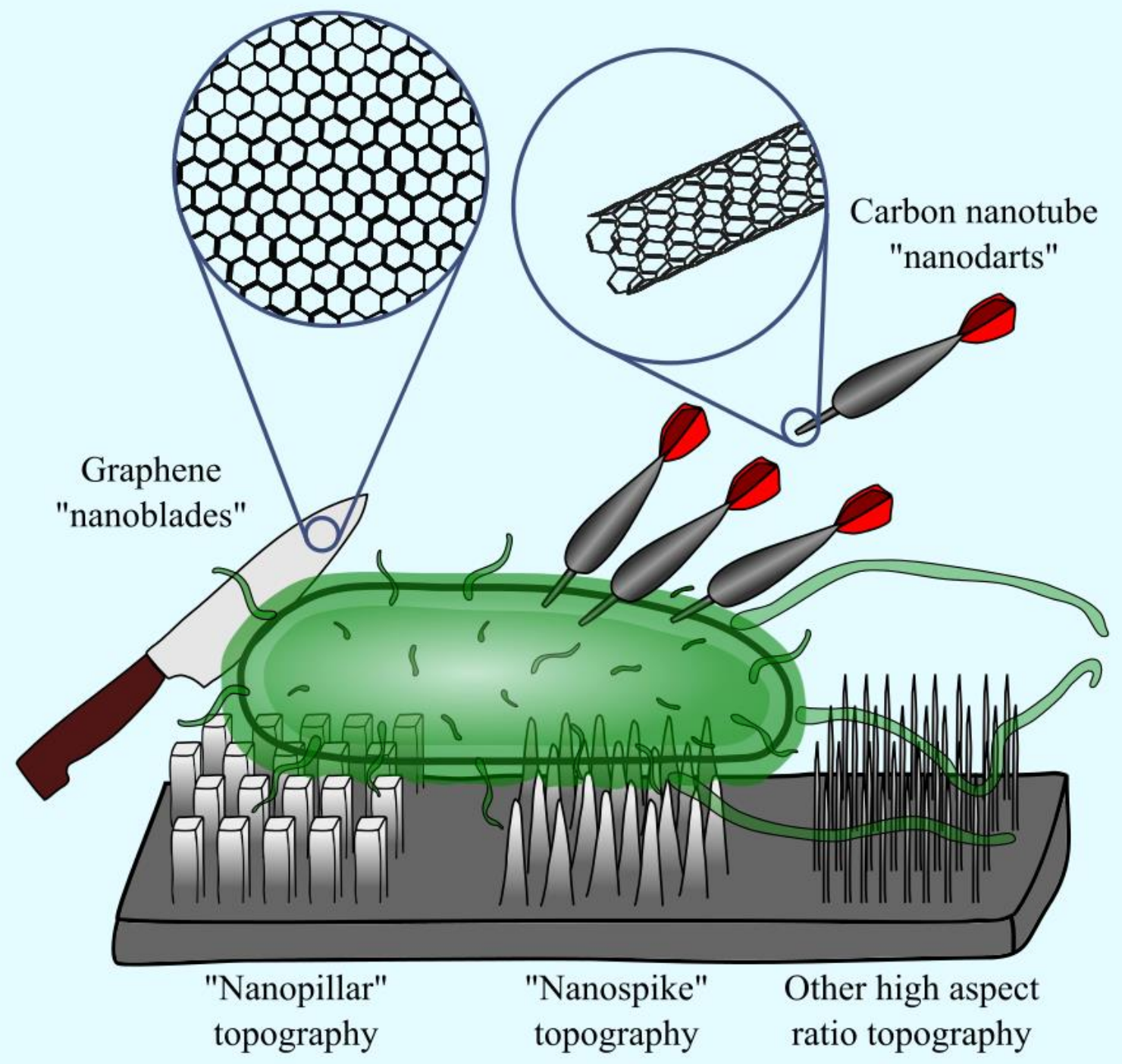

Figure 1. Mechano-bactericidal nanostructures can be designed to act as suspended colloidal systems, as is the case for carbon nanotubes and graphene nanosheets, or patterned as surface nanotopography, such as nanopillars and nanospikes. Note that the different components of this graphic are not drawn to scale. 

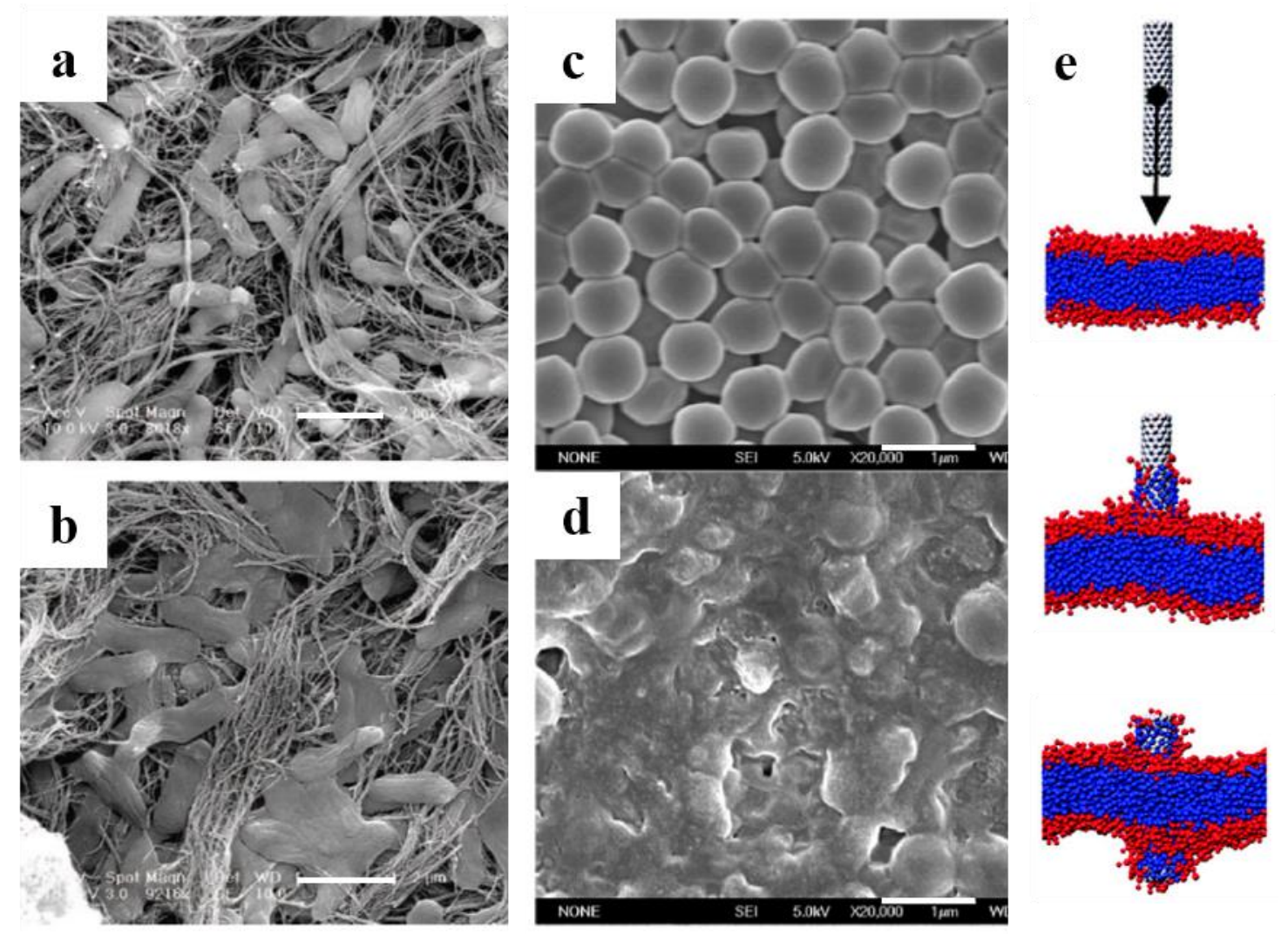

Figure 2. SEM images of E. coli cells exposed to (a) MWCNT aggregates for 60 min (scale bar: $2 \mu \mathrm{m}$ ) (b) and SWCNT aggregates for $60 \mathrm{~min}$ (scale bar: $2 \mu \mathrm{m}$ ), which produced higher mechano-bactericidal properties due to enhanced specific surface area available for contact. SEM images of S. aureus (c) incubated without SWCNTs (scale bar: $1 \mu \mathrm{m}$ ) (d) and after 2 h-incubation with pristine and dispersed SWCNTs (scale bar: $1 \mu \mathrm{m}$ ) show compromised cellular integrity. (e) Steered molecular dynamics pulling a SWCNT through a lipid bilayer reveals a perpendicular orientation requires less force to pull through compared to pulling CNT oriented in parallel. Lipids creep up the wall of the SWCNT during insertion and extracted lipids eventually block the tube ends. Images a), (b) adapted with permission from ref [22], copyright (2008) American Chemical Society (ACS), (c), (d) adapted with permission from ref [25], copyright (2009) ACS, (e), adapted with permission from [33], copyright (2008) ACS. 

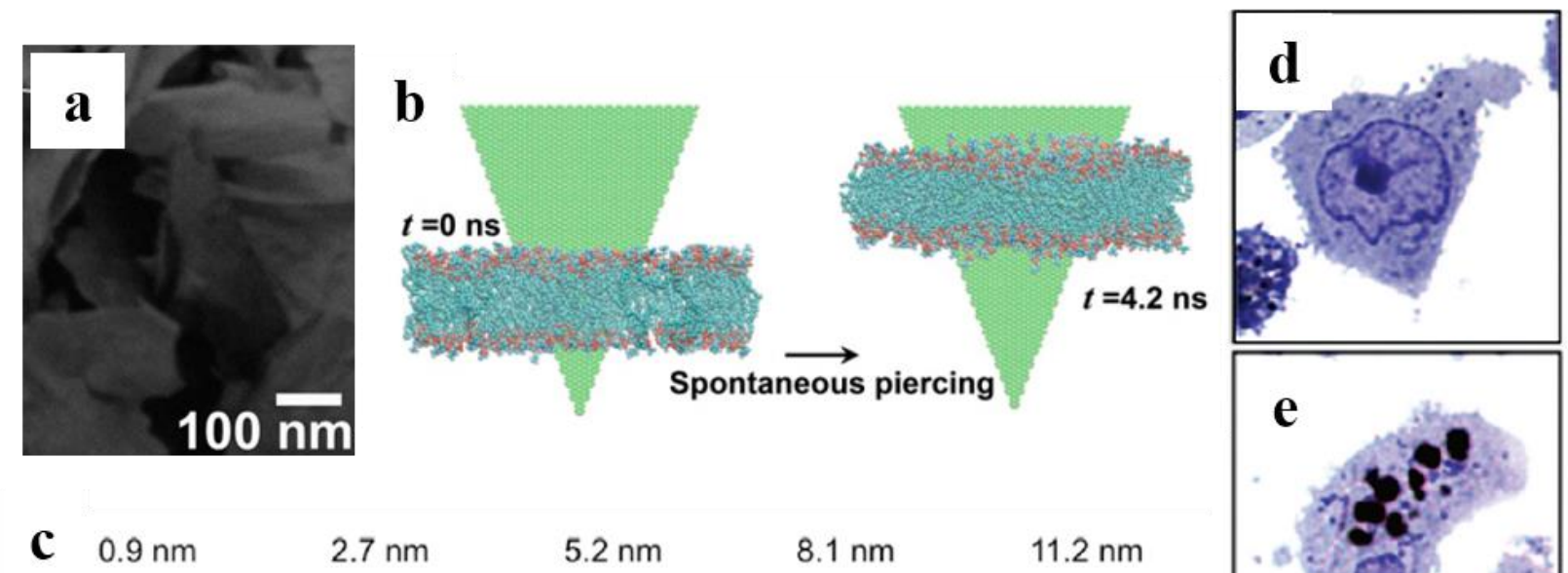

$2.7 \mathrm{~nm}$

$5.2 \mathrm{~nm}$

$8.1 \mathrm{~nm}$

$11.2 \mathrm{~nm}$
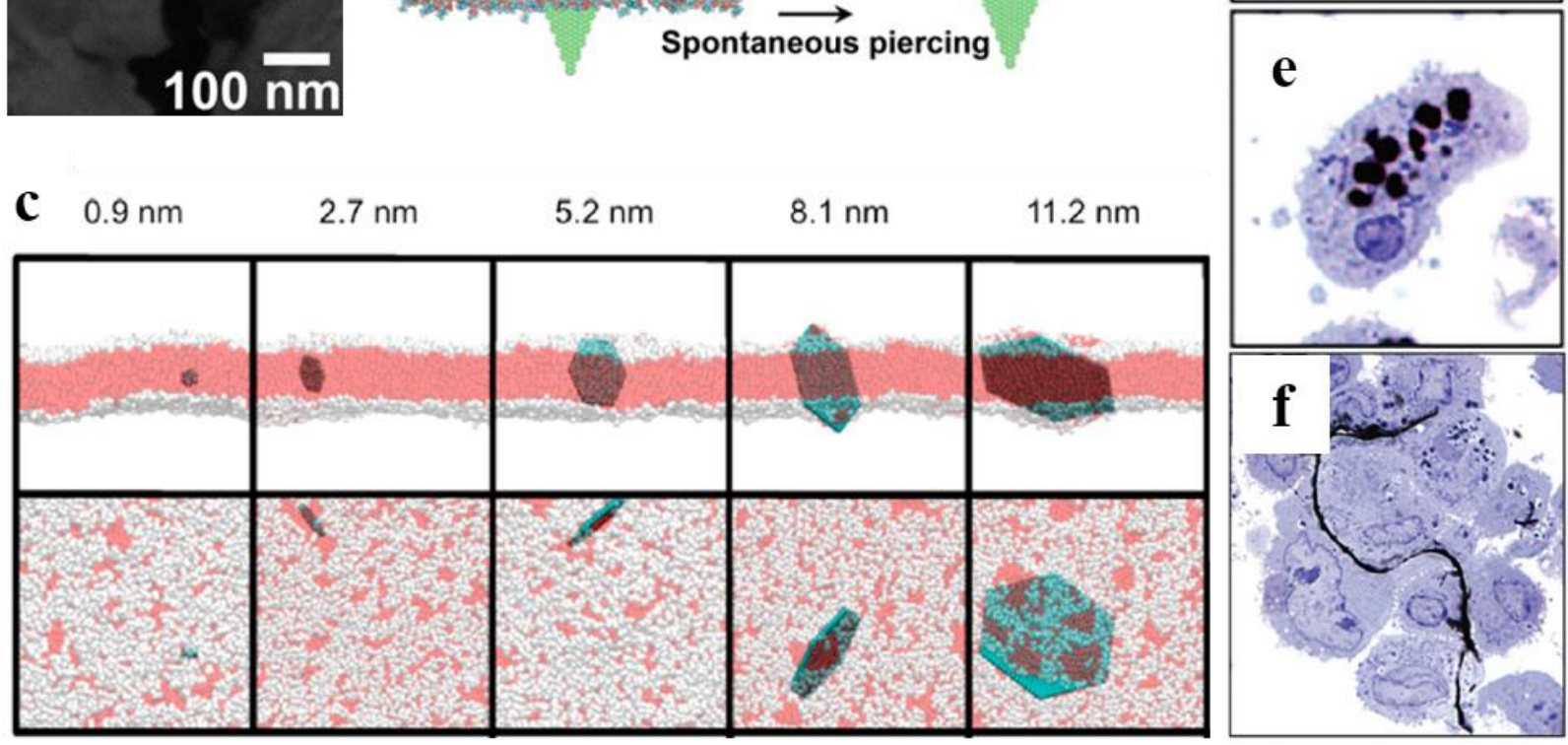

Figure 3. (a) Deposited GO nanosheets, some of which were standing perpendicular with respect to the substrate, killed S. aureus and E. coli. (b) All-atom molecular dynamics simulations of a monolayer graphene across a lipid bilayer shows corner asperities spontaneously pierce the membrane. (c) Other simulations found only smaller GFNs pierce membranes, whereas larger sheets would adhere flat atop the membrane. Further indications of a lateral dimension size-dependency in cellular interactions with GFNs can be observed when comparing at magnification of $1000 \times(d)$ untreated human macrophages to (e) cells treated with $550 \mathrm{~nm}$ GFN, which are readily internalized by the cell, while (f) $25 \mu \mathrm{m}$ GFNs wrap around cells instead of penetrating through the membrane. Image (a) adapted with permission from ref [46], copyright (2010) ACS, (b) adapted with permission from ref [53], copyright (2013) National Academy of Sciences, (c) adapted with permission from ref [55], copyright (2015) ACS, (d)-(f) adapted with permission from ref [17], copyright (2012) ACS. 

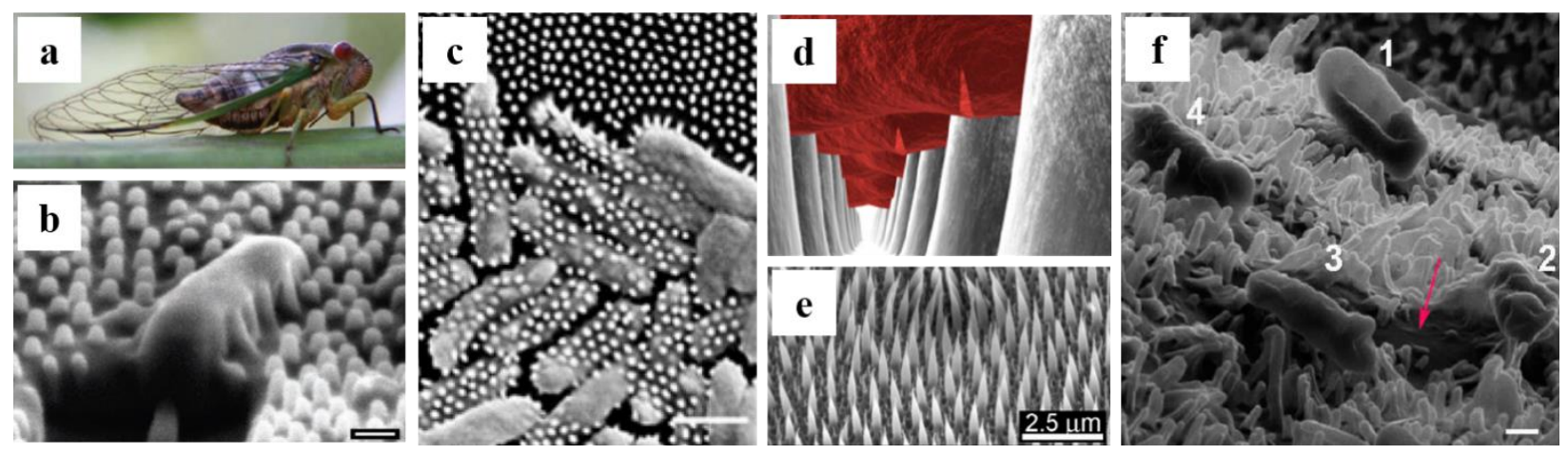

Figure 4. The wing of the (a) cicada insect was the first reported mechano-bactericidal nanotopography. (b) SEM image of a P. aeruginosa cell sinking between nanopillars of cicada wing (scale bar: $200 \mathrm{~nm}$ ). (c) Aerial view of nanopillars of cicada wing inducing mechano-bactericidal mode of action on P. aeruginosa leading to cell rupture (scale bar: $200 \mathrm{~nm}$ ) (d) Biophysical modeling of the outer layer of rod-shaped bacterial reveal nanopillars do not pierce. Instead, suspended regions of membrane rupture. (e) Mechanobactericidal nanotopography was also observed on the spinules of gecko skin. (f) Another proposed mechanism is that high adhesive forces between cellular EPS and the nanopillars (of dragonfly wing) as well as shear forces caused by struggling bacteria cause death (scale bar: $200 \mathrm{~nm}$ ). Images (a), (b) adapted with permission from ref [76], copyright (2012) John Wiley and Sons, (c) adapted with permission from ref [86], copyright (2013) Springer, (d) adapted with permission from ref [87], copyright (2013) Elsvier, (e) adapted with permission from ref [84], (2017) Nature Publishing Group, (f) adapted with permission from ref [81], copyright (2017) ACS. 


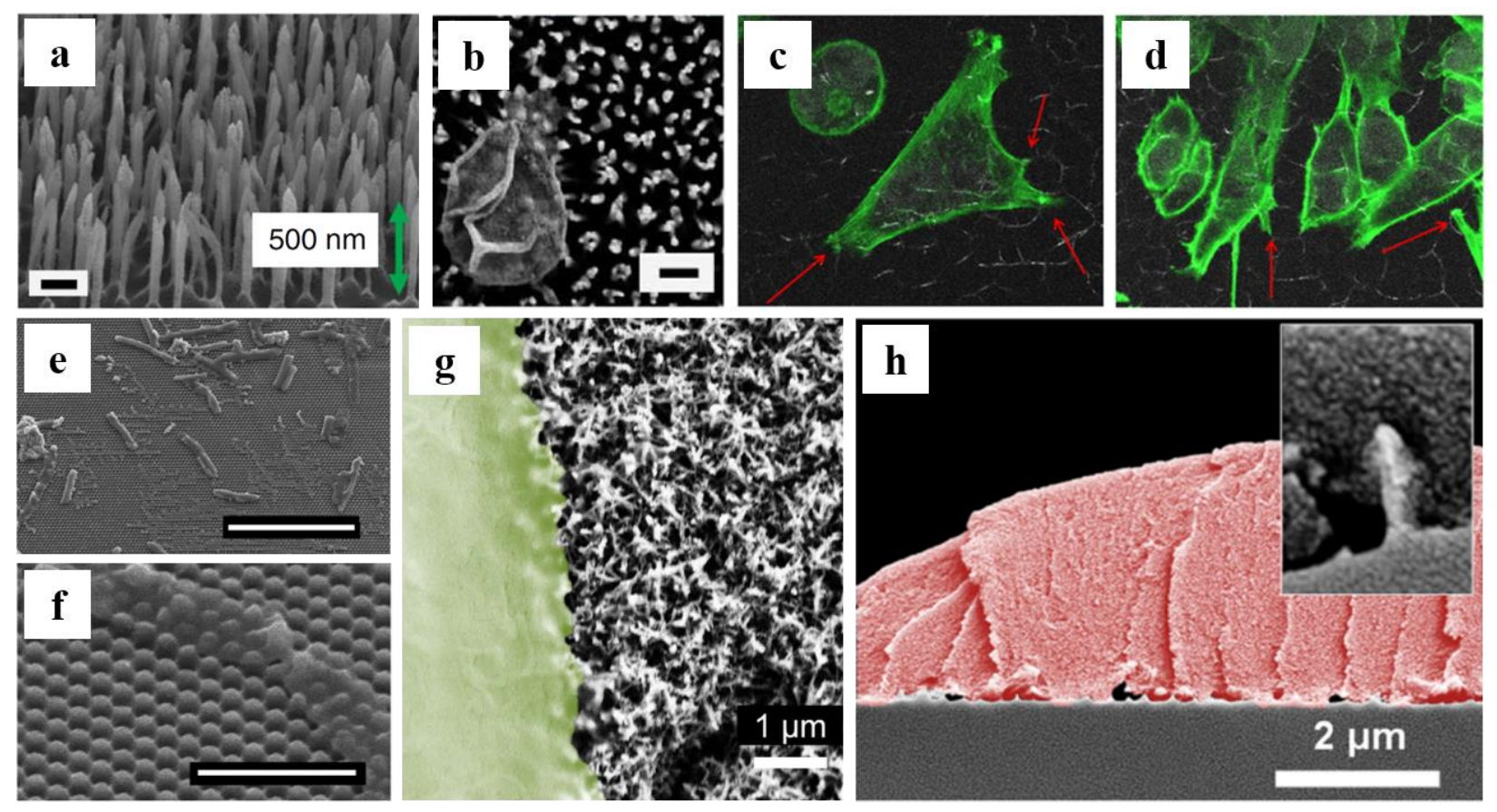

Figure 5. (a) Black silicon nanospikes fabricated by Ivanova et al. exhibit high aspect ratio capable of killing Gram-negative and Gram-positive bacteria and even (b) highly rigid endospores (scale bar: 200 $n m$ ). After four-day incubationupon bactericidal titania nanowire surfaces, (c) and (d), lamellipodia of mammalian cells migrated into pockets designed for mammalian cell interaction (scale bar not reported). (e) PMMA nanopillars were able to kill bacteria adhered to it (scale bar: $10 \mu \mathrm{m}$ ) with (f) $130-380 \mathrm{~nm}$ spacing between pillars being the optimally bactericidal (scale bar: $2 \mu \mathrm{m}$ ). (g) Anchorage points of a fibroblast cell interacting with mechano-bactericidal titanium nanowire surface. (b) The flexible membrane of mammalian cells can accommodate mechano-bactericidal nanotopography. Images (a), (b) adapted with permission from ref [94], copyright (2013) Nature Publishing Group, (c), (d) adapted with permission from ref [95], copyright (2014) Nature Publishing Group, (e), (f) adapted with permission

from ref [93], copyright (2015) AIP Publishing LLC, (g) adapted with permission from ref [104], copyright (2015) Nature Publishing Group, (b) adapted with permission from ref [99], copyright (2016) ACS. 
Table 1: CNTs as mechano-bactericidal colloids

\begin{tabular}{|c|c|c|c|}
\hline Colloid & $\begin{array}{l}\text { Mechano-bactericidal } \\
\text { nanostructure } \\
\text { (d: diameter) }\end{array}$ & Summary of findings & Reference \\
\hline CNTs & $\begin{array}{l}\text { SWCNT aggregates } \\
\text { (mean tube d: } 0.9 \mathrm{~nm})\end{array}$ & $\begin{array}{l}\text { First evidence of bacterial }(E \text {. coli) cell damage and } \\
\text { death by direct contact with CNTs }\end{array}$ & $\begin{array}{l}\text { Kang et al. } \\
\quad[21]\end{array}$ \\
\hline CNTs & $\begin{array}{l}\text { SWCNT aggregates } \\
\text { (mean tube d: } 0.9 \mathrm{~nm} \text {, } \\
\text { length: } 2 \mu \mathrm{m} \text { ) and } \\
\text { MWCNT aggregates } \\
\text { (mean tube d: } 30 \mathrm{~nm} \text {, length: } \\
70 \mu \mathrm{m} \text { ) }\end{array}$ & $\begin{array}{l}\text { Diameter of CNTs is a key factor: SWCNTs are } \\
\text { much more toxic to E. coli than MWCNTs. }\end{array}$ & $\begin{array}{l}\text { Kang et al. } \\
\quad[22]\end{array}$ \\
\hline CNTs & $\begin{array}{l}\text { Various MWCNT aggregates } \\
\text { (mean tube } \mathrm{d}: 17-35 \mathrm{~nm} \text {, } \\
\text { length: } 2.3-91 \mu \mathrm{m} \text { ) }\end{array}$ & $\begin{array}{l}\text { Higher toxicity towards E. coli is observed with } \\
\text { uncapped, debundled, short and dispersed } \\
\text { MWCNTs. }\end{array}$ & $\begin{array}{l}\text { Kang et al. } \\
\quad[23]\end{array}$ \\
\hline CNTs & $\begin{array}{l}\text { Individually dispersed } \\
\text { pristine SWCNT nanodarts } \\
\text { (mean tube } \mathrm{d}: 0.83 \mathrm{~nm}, \\
\text { length: } 1 \mu \mathrm{m})\end{array}$ & $\begin{array}{l}\text { Found physical puncture on bacteria (Gram- } \\
\text { negatives: } P \text {. aeruginosa and } E \text {. coli, Gram-positives: } \\
\text { S. aureus and } B \text {. subtilis) caused by nanodarts } \\
\text { improved by individually dispersing SWCNTs, } \\
\text { increasing SWCNT concentration, and elevating } \\
\text { shake speed of incubation. }\end{array}$ & Liu et al. [25] \\
\hline $\begin{array}{l}\text { Carbon } \\
\text { nanomaterials }\end{array}$ & $\begin{array}{l}\text { SWCNTs } \\
\text { (outer d: } 1-2 \mathrm{~nm} \text {, length: } 30 \\
\mu \mathrm{m}), \text { MWCNTs (outer d: } 8 \\
\text { nm, length: } 30 \mu \mathrm{m}), \mathrm{GO}^{\mathrm{a}} \\
\mathrm{rGO}^{\mathrm{a}} \text {, fullerene }\left(\mathrm{C}_{60}\right)\end{array}$ & $\begin{array}{l}\text { Needle-like SWCNTs and knife-like GO had } \\
\text { strongest antibacterial activity against copper- } \\
\text { resistant Ralstonia solanacearum by damaging cell } \\
\text { walls whereas the ball-like } \mathrm{C}_{60} \text { did not show } \\
\text { significant antibacterial activity. }\end{array}$ & $\begin{array}{l}\text { Wang et al. } \\
\qquad[27]\end{array}$ \\
\hline
\end{tabular}


Table 2. GFNs as mechano-bactericidal colloids

\begin{tabular}{|c|c|c|c|}
\hline Colloid & $\begin{array}{l}\text { Mechano-bactericidal } \\
\text { nanostructure } \\
\text { (d: diameter) }\end{array}$ & Summary of findings & Reference \\
\hline GFNs & $\begin{array}{l}\text { GO and reduced graphene } \\
\text { deposited on stainless steel }\end{array}$ & $\begin{array}{l}\text { Found direct contact between cell membrane and } \\
\text { extremely sharp edges of deposited graphene were } \\
\text { more effective against Gram-positive } S \text {. aureus } \\
\text { compared to Gram-negative } E \text {. coli. }\end{array}$ & $\begin{array}{c}\text { Akhavan et } \\
\text { al. }[46]\end{array}$ \\
\hline GFNs & $\begin{array}{l}\text { GO (thickness: }-0.8 \mathrm{~nm} \text { ) } \\
\text { magnetically-immobilized } \\
\text { and vertically aligned on glass }\end{array}$ & $\begin{array}{l}\text { Vertical alignment of GO nanosheets increased } \\
\text { density of edges causing enhanced physical } E \text {. coli } \\
\text { membrane penetration and chemical oxidation by } \\
\text { electron transfer. }\end{array}$ & Lu et al. [47] \\
\hline GFNs & $\begin{array}{c}\text { Graphite (size: } 6.87 \mu \mathrm{m}) \text {, } \\
\text { graphite oxide (size: } 6.28 \\
\mu \mathrm{m}) \text {, reduced GO (size: } 2.75 \\
\mu \mathrm{m}), \text { GO (size: } 0.31 \mu \mathrm{m})\end{array}$ & $\begin{array}{l}\text { E. coli incubated with dispersions of GFNs then } \\
\text { assessed by SEM showed cell damage after direct } \\
\text { contact (similar to CNTs) but cell death was due to } \\
\text { a combination of membrane damage and oxidative } \\
\text { stress. }\end{array}$ & Liu et al. [48] \\
\hline GFNs & GO (mean thickness: $1 \mathrm{~nm}$ ) & $\begin{array}{l}\text { GO caused integrity loss of cell membrane and cell } \\
\text { wall of dental pathogens (Streptococcus mutans, } \\
\text { Fusobacterium nucleatum, Porphyromonas gingivalis) } \\
\text { based on TEM, attributed to physical mechanism } \\
\text { of GO which insert/cut through membranes and } \\
\text { destructively extract phospholipids. }\end{array}$ & He et al. [52] \\
\hline $\begin{array}{c}\text { Carbon } \\
\text { nanomaterials }\end{array}$ & $\begin{array}{l}\text { SWCNTs (outer d: } 1-2 \mathrm{~nm} \text {, } \\
\text { length: } 30 \mu \mathrm{m}), \text { MWCNTs } \\
\text { (outer d: } 8 \mathrm{~nm} \text {, length: } 30 \\
\mu \mathrm{m}), \mathrm{GO}^{\mathrm{a}}, \mathrm{rGO}^{\mathrm{a}} \text {, fullerene } \\
\left(\mathrm{C}_{60}\right)\end{array}$ & $\begin{array}{l}\text { Needle-like SWCNTs and knife-like GO had } \\
\text { strongest antibacterial activity against copper- } \\
\text { resistant Ralstonia solanacearum by damaging cell } \\
\text { walls whereas the ball-like } \mathrm{C}_{60} \text { did not show } \\
\text { significant antibacterial activity. }\end{array}$ & $\begin{array}{l}\text { Wang et al. } \\
{[27]}\end{array}$ \\
\hline
\end{tabular}


Table 3. Natural mechano-bactericidal nanotopographies

\begin{tabular}{|c|c|c|c|}
\hline Material & $\begin{array}{l}\text { Mechano-bactericidal } \\
\text { nanostructure } \\
\text { (h: height; d: diameter) }\end{array}$ & Summary of findings & Reference \\
\hline Cicada wing & $\begin{array}{l}\text { Nanopillars } \\
\text { (h: } 200 \mathrm{~nm} \text {, base d: } 100 \mathrm{~nm} \text {, } \\
\text { tip d: } 60 \mathrm{~nm} \text { ) }\end{array}$ & $\begin{array}{c}\text { First reported example of mechano-bactericidal } \\
\text { nanotopography but only effective against } P \text {. } \\
\text { aeruginosa. }\end{array}$ & $\begin{array}{c}\text { Ivanova et al. } \\
{[76]}\end{array}$ \\
\hline $\begin{array}{l}\text { Cicada wings } \\
\text { (3 species) }\end{array}$ & $\begin{array}{l}\text { Nanopillars } \\
\text { (h: } 241 \mathrm{~nm}, \mathrm{~d}: 156 \mathrm{~nm} \text {; } \\
\text { h: } 182 \mathrm{~nm}, \mathrm{~d}: 159 \mathrm{~nm} \text {; } \\
\text { h: } 182 \mathrm{~nm}, \mathrm{~d}: 207 \mathrm{~nm} \text { ) }\end{array}$ & $\begin{array}{l}\text { Antibacterial against Pseudomonas fluorescens } \\
\text { (Gram-negative). The more nanostructures cells } \\
\text { come into contact with, the greater the bactericidal } \\
\text { activity, suggesting reducing pitch and diameter of } \\
\text { features are more effective. }\end{array}$ & $\begin{array}{l}\text { Kelleher et al. } \\
\text { [92] }\end{array}$ \\
\hline $\begin{array}{l}\text { Cicada ( } 2 \\
\text { species) and } \\
\text { dragonfly } \\
\text { wings }\end{array}$ & $\begin{array}{l}\text { Hemispheres } \\
\text { (h: } 84 \mathrm{~nm} \text {, width: } 167 \mathrm{~nm} \text { ), } \\
\text { spherically capped cones } \\
\text { (h: } 183 \mathrm{~nm} \text {, base width: } 104 \\
\text { nm, cap width: } 57 \mathrm{~nm} \text { ), } \\
\text { spherically capped cylinders } \\
\text { (h: } 241 \mathrm{~nm} \text {, width: } 53 \mathrm{~nm} \text { ) }\end{array}$ & $\begin{array}{l}\text { Strains of Saccharomyces cerevisiae (yeast) experience } \\
\text { rupture similar to bacterial cell death despite } \\
\text { differences in cell wall structure. Adhesion of cell to } \\
\text { the nanostructured topography stretches and } \\
\text { distorts it with cell derived material or debris } \\
\text { flowing and "puddling" into topography. }\end{array}$ & $\begin{array}{c}\text { Nowlin et al. } \\
\text { [98] }\end{array}$ \\
\hline $\begin{array}{l}\text { Cicada wing } \\
\text { and PMMA }\end{array}$ & $\begin{array}{l}\text { Wing nanopillars } \\
\text { (h: } 210 \mathrm{~nm}, \mathrm{~d}: 60 \mathrm{~nm} \text { ), } \\
\text { PMMA nanopillars } \\
\text { (h: } 300 \mathrm{~nm}, \mathrm{~d}: 215 \mathrm{~nm} \\
\text { h: } 300 \mathrm{~nm}, \mathrm{~d}: 190 \mathrm{~nm} \\
\text { h: } 210 \mathrm{~nm} \text {, tip d: } 70 \mathrm{~nm} \text { ) }\end{array}$ & $\begin{array}{c}\text { First polymer mechano-bactericidal } \\
\text { nanotopography. Smaller, closely spaced (between } \\
130-380 \mathrm{~nm} \text { ) PMMA nanopillars were optimally } \\
\text { bactericidal against } E \text {. coli. }\end{array}$ & $\begin{array}{l}\text { Dickson et } \\
\text { al. }[93]\end{array}$ \\
\hline $\begin{array}{l}\text { Dragonfly } \\
\text { wing and } \\
\text { silicon }\end{array}$ & $\begin{array}{c}\text { Wing nanopillars } \\
\text { (h: } 240 \mathrm{~nm}, \mathrm{~d}:<90 \mathrm{~nm} \text { ) and } \\
\text { nanospikes } \\
\text { (h: } 240 \mathrm{~nm}, \mathrm{~d}:<30 \mathrm{~nm} \text { ). } \\
\text { Silicon nanospikes } \\
\text { (h: } 279 \mathrm{~nm}, \mathrm{~d}: 62 \mathrm{~nm} \text { ), } \\
\text { nanospikes } \\
\text { (h: } 433 \mathrm{~nm}, \mathrm{~d}: 80 \mathrm{~nm} \text { ), } \\
\text { nanospikes } \\
\text { (h: } 612 \mathrm{~nm}, \mathrm{~d}: 93 \mathrm{~nm} \text { ) }\end{array}$ & $\begin{array}{c}\text { Effective against Gram-negative (P. aeruginosa) and } \\
\text { Gram-positive (B. subtilis) bacteria and endospores. } \\
\text { First reported artificial and biomimetic mechano- } \\
\text { bactericidal nanotopography. Effective against } P \text {. } \\
\text { aeruginosa and } B \text {. subtilis bacteria and } B \text {. subtilis } \\
\text { endospores. }\end{array}$ & $\begin{array}{c}\text { Ivanova et al. } \\
\text { [94] }\end{array}$ \\
\hline $\begin{array}{l}\text { Dragonfly } \\
\text { wings } \\
\text { (3 species) }\end{array}$ & $\begin{array}{c}\text { Nanopillars } \\
\text { (h: } 200-300 \mathrm{~nm}, \mathrm{~d}: 80 \mathrm{~nm})\end{array}$ & $\begin{array}{l}\text { Assessed } P \text {. aeruginosa, } B \text {. subtilis and endospores to } \\
\text { show species-dependent trend in bactericidal } \\
\text { efficiency depending on evolution. }\end{array}$ & $\begin{array}{l}\text { Mainwaring } \\
\text { et al. }[82]\end{array}$ \\
\hline $\begin{array}{l}\text { Dragonfly } \\
\text { wing }\end{array}$ & $\begin{array}{l}\text { Bimodal, short nanopillars } \\
\text { (h: } 189 \mathrm{~nm}, \mathrm{~d}: 37 \mathrm{~nm} \text { ) and } \\
\text { tall nanopillars } \\
\text { (h: } 311 \mathrm{~nm}, \mathrm{~d}: 57 \mathrm{~nm})\end{array}$ & $\begin{array}{c}\text { Using } E \text {. coli, suggested cell membrane damage is a } \\
\text { combination of strong adhesion between } \\
\text { nanopillars and bacterium as well as shear forces } \\
\text { due to movement of adhered bacterium during } \\
\text { struggle on nanopillars }\end{array}$ & $\begin{array}{c}\text { Bandara et al. } \\
{[81]}\end{array}$ \\
\hline $\begin{array}{l}\text { Damselfly } \\
\text { wing }\end{array}$ & $\begin{array}{c}\text { Nanoprotrusions } \\
\text { (h: } 433 \mathrm{~nm} \text {, tip d: } 48 \mathrm{~nm} \text { ) }\end{array}$ & $\begin{array}{l}\text { Young and late-stationary phase bacterial cells } \\
\text { (P. aeruginosa, } S \text {. aureus) were most susceptible. } \\
\text { Mature cells were more resilient. }\end{array}$ & $\begin{array}{l}\text { Truong et al. } \\
{[80]}\end{array}$ \\
\hline Gecko skin & Spinules & $\begin{array}{l}\text { Gecko skin kills } P \text {. gingivalis (Gram-negative) but } \\
\text { demonstrated eukaryotic cell compatibility with } \\
\text { human dental pulp stem cells. }\end{array}$ & $\begin{array}{l}\text { Watson et al. } \\
{[85]}\end{array}$ \\
\hline
\end{tabular}




\begin{tabular}{|c|c|c|c|}
\hline & $\begin{array}{l}\text { (h: }<4 \mu \mathrm{m} \text {, terminating with } \\
\text { spherical cap of small radius } \\
\text { of curvature }-10-30 \mathrm{~nm} \text { ) }\end{array}$ & & \\
\hline $\begin{array}{l}\text { Gecko skin } \\
\text { and epoxy } \\
\text { resin replica }\end{array}$ & $\begin{array}{l}\text { Spinules } \\
\text { (h: } 2-4 \mu \mathrm{m})\end{array}$ & $\begin{array}{l}\text { Death of } S . \text { mutans and } P \text {. gingivalis (Gram- } \\
\text { negative) is caused by cell compression and } \\
\text { stretching. More successful against Gram-negative } \\
\text { than Gram-positive bacteria. }\end{array}$ & Li et al. [83] \\
\hline $\begin{array}{l}\text { Gecko skin } \\
\text { and } \\
\text { biopolymer } \\
\text { blend replica }\end{array}$ & $\begin{array}{c}\text { Spinules } \\
\text { (h: } 1-4 \mu \mathrm{m} \text { and taper to }<50 \\
\mathrm{~nm} \text { nanotip) }\end{array}$ & $\begin{array}{l}\text { A biotemplating method to replicate the spinules } \\
\text { covering gecko lizard skin is described. Gut bacteria } \\
\text { cultivated on natural and replica gecko skin } \\
\text { experienced rupture and death on spinules. }\end{array}$ & $\begin{array}{c}\text { Green } e t a l . \\
\text { [84] }\end{array}$ \\
\hline
\end{tabular}


Table 4. Biomimetic and bio-inspired mechano-bactericidal nanotopographies

\begin{tabular}{|c|c|c|c|}
\hline Material & $\begin{array}{l}\text { Mechano-bactericidal } \\
\text { nanostructure } \\
\text { (h: height; d: diameter) }\end{array}$ & Summary of findings & Reference \\
\hline $\begin{array}{l}\text { Gecko skin } \\
\text { and epoxy } \\
\text { resin replica }\end{array}$ & $\begin{array}{c}\text { Spinules } \\
(\mathrm{h}: 2-4 \mu \mathrm{m})\end{array}$ & $\begin{array}{l}\text { Death of } S \text {. mutans and } P \text {. gingivalis (Gram- } \\
\text { negative) is caused by cell compression and } \\
\text { stretching. More successful against Gram-negative } \\
\text { than Gram-positive bacteria. }\end{array}$ & Li et al. [83] \\
\hline $\begin{array}{l}\text { Gecko skin } \\
\text { and } \\
\text { biopolymer } \\
\text { blend replica }\end{array}$ & $\begin{array}{c}\text { Spinules } \\
\text { (h: } 1-4 \mu \mathrm{m} \text { and taper to }<50 \\
\text { nm nanotip) }\end{array}$ & $\begin{array}{l}\text { A biotemplating method to replicate the spinules } \\
\text { covering gecko lizard skin is described. Gut bacteria } \\
\text { cultivated on natural and replica gecko skin } \\
\text { experienced rupture and death on spinules. }\end{array}$ & $\begin{array}{l}\text { Green et al. } \\
\text { [84] }\end{array}$ \\
\hline Silicon & $\begin{array}{l}\text { Nanopillars } \\
\text { (h: } 279 \mathrm{~nm}, \mathrm{~d}: 62 \mathrm{~nm} \text {; } \\
\text { h: } 433 \mathrm{~nm}, \mathrm{~d}: 80 \mathrm{~nm} \text {; } \\
\text { h: } 612 \mathrm{~nm}, \mathrm{~d}: 93 \mathrm{~nm} \text { ) }\end{array}$ & $\begin{array}{l}\text { Time-dependent plasma etching of silicon produces } \\
\text { different heights. Incubation with Gram-positive } S \text {. } \\
\text { aureus and Gram-negative } P \text {. aeruginosa showed } \\
\text { smaller, more densely packed pillars exhibit greatest } \\
\text { bactericidal activity. }\end{array}$ & $\begin{array}{l}\text { Linklater et } \\
\text { al. [79] }\end{array}$ \\
\hline Silicon & $\begin{array}{c}\text { Nanopillars } \\
(\mathrm{h}:-652 \mathrm{~nm}, \mathrm{~d}:-100 \mathrm{~nm})\end{array}$ & $\begin{array}{l}\text { Substrate preinfected with } P \text {. aeruginosa or } S \text {. aureus } \\
\text { then incubated with fibroblast cells prevented } \\
\text { bacterial colonization while enabling eukaryotic } \\
\text { proliferation. The substrate did not trigger in vivo } \\
\text { inflammatory response in mice. }\end{array}$ & $\begin{array}{c}\text { Pham et al. } \\
\text { [99] }\end{array}$ \\
\hline Silicon & $\begin{array}{c}\text { Nanospikes } \\
\text { (h: } 500 \mathrm{~nm}, \mathrm{~d}: 95 \mathrm{~nm})\end{array}$ & $\begin{array}{l}\text { A microfluidic device incorporating bactericidal } \\
\text { black silicon substratum was effective in killing } E \text {. } \\
\text { coli and } P \text {. aeruginos } a \text { under fluid flow. }\end{array}$ & $\begin{array}{l}\text { Wang et al. } \\
\qquad[101]\end{array}$ \\
\hline Silicon & $\begin{array}{c}\text { Nanopillars } \\
\text { (d: } 150-200 \mathrm{~nm})\end{array}$ & $\begin{array}{c}\text { Nanopillars prepared by maskless plasma etching } \\
\text { were bactericidal against } E \text {. coli, } S \text {. aureus and } \\
\text { Bacillus cereus (Gram-positive). }\end{array}$ & $\begin{array}{c}\text { Vassallo et al. } \\
\text { [102] }\end{array}$ \\
\hline Titanium & $\begin{array}{l}\text { Nanopillars } \\
\text { (d: } 200-300 \mathrm{~nm}) \\
\text { and nanospikes } \\
(\mathrm{d}: 20 \mathrm{~nm})\end{array}$ & $\begin{array}{c}\text { Titanium nanospikes fabricated by thermal } \\
\text { oxidation showed } 40 \% \text { reduction of } E \text {. coli. Similar } \\
\text { bactericidal efficacy between nanopillars and } \\
\text { nanospikes. }\end{array}$ & $\begin{array}{l}\text { Sjostrom et } \\
\text { al. }[103]\end{array}$ \\
\hline Titanium & $\begin{array}{l}\text { Titanium (357 } \mathrm{nm} \\
\text { nanoroughness) and } \\
\text { hydrothermally etched } \\
\text { titanium ( } 401 \mathrm{~nm} \\
\text { nanoroughness, nanowires } 40 \\
\mathrm{~nm} \text { in height) }\end{array}$ & $\begin{array}{c}\text { Etched titanium was more bactericidal against } P \text {. } \\
\text { aeruginosa ( } 53 \% \text { viable) than } S \text {. aureus }(80 \% \\
\text { viable). The same substrate enhanced proliferation } \\
\text { of human fibroblast growth. }\end{array}$ & $\begin{array}{c}\text { Bhadra et al. } \\
\text { [104] }\end{array}$ \\
\hline Titanium & $\begin{array}{c}\text { Nanopillars } \\
\text { (h: } 1 \mu \mathrm{m}, \mathrm{d}: 80 \mathrm{~nm})\end{array}$ & $\begin{array}{l}\text { Observed mechanical rupturing of } E \text {. coli, } P \text {. } \\
\text { aeruginosa, } S \text {. aureus, and Mycobacterium smegmatis } \\
\text { (Gram-positive) cells. Also supported attachment } \\
\text { and proliferation of mammalian cells. }\end{array}$ & $\begin{array}{c}\text { Hasan et al. } \\
{[105]}\end{array}$ \\
\hline Titanium & $\begin{array}{l}\text { Sharp-edged titanium } \\
\text { columns } \\
\text { (h: } 478 \mathrm{~nm})\end{array}$ & $\begin{array}{l}\text { Damaged morphology of } E \text {. coli while morphology } \\
\text { of } S \text {. aureus was unaffected. Possibly related to } \\
\text { movement of cell body during cell division. } \\
\text { Mammalian cells grown on nanotopography were } \\
\text { no different than control. }\end{array}$ & $\begin{array}{l}\text { Sengstock et } \\
\text { al. [96] }\end{array}$ \\
\hline
\end{tabular}




\begin{tabular}{|c|c|c|c|}
\hline $\begin{array}{l}\text { Titania on } \\
\text { titanium } \\
\text { substrate }\end{array}$ & $\begin{array}{l}\text { Titanium dioxide nanowire } \\
\text { brushes } \\
\text { (h: } 3 \mu \mathrm{m}, \mathrm{d}: 100 \mathrm{~nm} \text { ), } \\
\text { nanowire niches } \\
\text { (h: } 3 \mu \mathrm{m}, \mathrm{d}: 10-15 \mu \mathrm{m} \text { ) }\end{array}$ & $\begin{array}{l}\text { Selectively bactericidal against motile bacteria } P \text {. } \\
\text { aeruginosa, E. coli, and } B \text {. subtilis. Non-motile } S \text {. } \\
\text { aureus, E. faecalis and } K \text {. pneumonia were not } \\
\text { strongly affected. The same surfaces were capable of } \\
\text { guiding mammalian cell proliferation. }\end{array}$ & $\begin{array}{c}\text { Diu et al. } \\
\text { [95] }\end{array}$ \\
\hline $\begin{array}{l}\text { Titania on } \\
\text { titanium } \\
\text { substrate }\end{array}$ & $\begin{array}{l}\text { Nanowires with spike-like } \\
\text { structures } \\
\text { (h: } 1 \mu \mathrm{m}, \mathrm{d}: 25 \mathrm{~nm} \text { ) and } \\
\text { brush-like structures } \\
\text { (h: } \sim 2 \mu \mathrm{m}, \mathrm{d}: 222 \mathrm{~nm} \text { ) }\end{array}$ & $\begin{array}{l}\mathrm{TiO}_{2} \text { nanowires on titanium substrates supported } \\
\text { osteoblast and osteoclast growth and differentiation } \\
\text { while reducing bacterial viability of } P \text {. aeruginosa. } \\
\text { Killing efficiency was } 30 \% \text { and } 58 \% \text { after } 1 \mathrm{~h} \text { and } \\
18 \mathrm{~h} \text {, respectively. }\end{array}$ & $\begin{array}{c}\text { Tsimbouri } e t \\
\text { al. }[100]\end{array}$ \\
\hline Gold & $\begin{array}{c}\text { Nanopillars } \\
\text { (h: }-100 \mathrm{~nm}, \mathrm{~d}:-50 \mathrm{~nm}) \\
\text { and other topographical } \\
\text { nanostructures (nanoring, } \\
\text { nanonugget) }\end{array}$ & $\begin{array}{c}\text { Number of live } S \text {. aureus cells on all gold } \\
\text { nanotopographies was } 3 \text { orders of magnitude lower } \\
\text { than on flat and rough control surfaces. All three } \\
\text { nanostructures delivered similar bactericidal } \\
\text { performance. }\end{array}$ & $\begin{array}{c}\text { Wu et al. } \\
{[106]}\end{array}$ \\
\hline $\begin{array}{l}\text { Diamond on } \\
\text { silicon wafer }\end{array}$ & $\begin{array}{l}\text { Nanocones } \\
\text { (h: } 0.8-2.5 \mu \mathrm{m} \text {, width: } 350- \\
750 \mathrm{~nm} \text { ), bimodal nanocones } \\
\text { (h: } 100 \mathrm{~nm} \text { or } 3-5 \mu \mathrm{m} \\
\text { width: } 10-40 \mathrm{~nm} \text { ). }\end{array}$ & $\begin{array}{c}\text { Diamond nanocones with varying cone dimensions, } \\
\text { non-uniform array and decreased density was more } \\
\text { bactericidal than highly dense nanocone surface } \\
\text { against } P \text {. aeruginosa. Morphological damage varied } \\
\text { despite cell death. }\end{array}$ & $\begin{array}{c}\text { Fisher et al. } \\
\quad[91]\end{array}$ \\
\hline $\begin{array}{l}\text { Diamond } \\
\text { coated } \\
\text { nanopillared } \\
\text { silicon wafer }\end{array}$ & $\begin{array}{l}\text { Short silicon needles } \\
\text { (h: } 1 \mu \mathrm{m} \text { ) or long silicon } \\
\text { needles (h: } 15-20 \mu \mathrm{m} \text { ) both } \\
\text { coated with } 10 \mathrm{~nm} \\
\text { nanodiamond }\end{array}$ & $\begin{array}{l}\text { Bactericidal properties of diamond-coated silicon } \\
\text { needles against } P \text {. aeruginosa was evident after } 1 \\
\text { hour (13\% dead compared to } 2 \% \text { flat control). } \\
\text { Cells appeared to be damaged by nanofeatures, } \\
\text { appearing flat and non-turgid. }\end{array}$ & $\begin{array}{c}\text { May et al. } \\
{[107]}\end{array}$ \\
\hline GO film & $\begin{array}{l}\text { Various highly wrinkled and } \\
\text { rough GO (h: } 0.74-2.1 \mu \mathrm{m} \\
\text { depending on roughness, } \\
\text { width of each wall of } \\
\text { wrinkles: } 7.75-15.2 \mu \mathrm{m})\end{array}$ & $\begin{array}{l}\text { Wrinkled GO films prepared by vacuum filtration } \\
\text { of GO suspensions form mechanically robust GO } \\
\text { "traps" resulting in damage to the cell membranes } \\
\text { of E. coli, S. aureus, and M. smegmatis caused by } \\
\text { increased oxidative stress and physical piercing or } \\
\text { laceration. }\end{array}$ & $\begin{array}{l}\text { Zou et al. } \\
\quad[108]\end{array}$ \\
\hline $\begin{array}{l}\text { Zeolitic } \\
\text { imidazolate } \\
\text { framework } \\
\text { (ZIF) on } \\
\text { various } \\
\text { substrates }\end{array}$ & $\begin{array}{c}\text { ZIF Nano-daggers } \\
\text { (h: }>1 \mu \mathrm{m}, 2 \mu \mathrm{m} \text { thick with } \\
\text { sharp nanotips) }\end{array}$ & $\begin{array}{l}\text { High bactericidal activity against E. coli, S. aureus, } \\
\text { and Candida albicans (fungi) hypothesized to be } \\
\text { caused by enhanced cell adhesion by positively } \\
\text { charged ZIF followed by killing by rigid and sharp } \\
\text { nano-dagger tips. }\end{array}$ & $\begin{array}{c}\text { Yuan et al. } \\
\text { [109] }\end{array}$ \\
\hline
\end{tabular}

